\title{
Neurochemical and electrical modulation of the locus coeruleus: contribution to $\mathrm{CO}_{2}$ drive to breathe
}

\section{Débora de Carvalho, Luis G. A. Patrone, Camila L. Taxini, Vivian Biancardi, Mariane C. Vicente and Luciane H. Gargaglioni*}

Department of Animal Morphology and Physiology, Faculty of Agricultural and Veterinarian Sciences, Universidade Estadual Paulista - São Paulo State University, Jaboticabal, Brazil

\section{Edited by:}

Thiago S. Moreira, University of São Paulo, Brazil

Reviewed by:

David D. Kline, University of Missouri, USA

Thiago S. Moreira, University of São Paulo, Brazil

\section{*Correspondence:}

Luciane H. Gargaglioni, Department of Animal Morphology and Physiology, Faculty of Agricultural and Veterinarian Sciences, Universidade Estadual Paulista - São Paulo State University, Rod. Prof. Paulo Donato Castellane s/n, 14870-000 Jaboticabal, São

Paulo, Brazil

e-mail: lucihel@fcav.unesp.br
The locus coeruleus (LC) is a dorsal pontine region, situated bilaterally on the floor of the fourth ventricle. It is considered to be the major source of noradrenergic innervation in the brain. These neurons are highly sensitive to $\mathrm{CO}_{2} / \mathrm{pH}$, and chemical lesions of LC neurons largely attenuate the hypercapnic ventilatory response in unanesthetized adult rats. Developmental dysfunctions in these neurons are linked to pathological conditions such as Rett and sudden infant death syndromes, which can impair the control of the cardiorespiratory system. LC is densely innervated by fibers that contain glutamate, serotonin, and adenosine triphosphate, and these neurotransmitters strongly affect LC activity, including central chemoreflexes. Aside from neurochemical modulation, LC neurons are also strongly electrically coupled, specifically through gap junctions, which play a role in the $\mathrm{CO}_{2}$ ventilatory response. This article reviews the available data on the role of chemical and electrical neuromodulation of the LC in the control of ventilation.

Keywords: rodent, chemosensitive signaling, serotonin, glutamate, hypercapnia, ATP

\section{INTRODUCTION}

Locus coeruleus (LC) is pontine region situated bilaterally on the floor of the fourth ventricle, and produces the majority of noradrenaline (NA) in the forebrain. The LC region is a densely packed nucleus, comprising about 1500 neurons per side (Aston-Jones et al., 1984). The first description of the LC was published by Reil (1809), but the term LC was proposed by the anatomists Wenzel and Wenzel in 1812 (reviewed by Russell, 1955). In addition to NA, the cell bodies also secret several neuropeptides (Sutin and Jacobowitz, 1991), among which are vasopressin, somatostatin, neuropeptide Y, enkephalin, neurotensin, CRH, and galanin (for review, see Olpe and Steinmann, 1991). This nucleus has been described in a wide variety of animals, such as frogs, birds, rodents, and primates (González and Smeets, 1993).

LC NA neurons projects broadly throughout the neuraxis, from spinal cord to neocortex (Swanson and Hartman, 1975; Foote et al., 1983; Berridge and Waterhouse, 2003). In fact, it is estimated that $\sim 50 \%$ of all the noradrenergic projections in the central nervous system (CNS) originate in the LC which are directed toward the forebrain, cerebellum, brainstem and spinal cord (Aston-Jones et al., 1995; Berridge and Waterhouse, 2003). LC is the primary source of an extensive, yet regionally specialized, noradrenergic innervation of the forebrain (Berridge and Waterhouse, 2003) and it is considered a major wakefulness promoting nucleus with activation of the LC resulting in an increase in EEG signs of alertness (Samuels and Szabadi, 2008).

The alerting effect of LC activation results from dense excitatory projections to the cerebral cortex, dorsal raphe, pedunculopontine tegmental nucleus and the laterodorsal tegmental nucleus, and from substantial inhibitory projections to sleep-promoting GABAergic neurons of the basal forebrain and the ventrolateral preoptic area (Samuels and Szabadi, 2008). Additionally, LC also modulates autonomic function through direct output to sympathetic and parasympathetic preganglionic neurons of the intermediolateral cell column of the spinal cord and to projections innervating other autonomic nuclei (Nygren and Olson, 1977; Westlund etal., 1983; Jones and Yang, 1985), among which known examples are the Edinger-Westphal Nucleus (Breen et al., 1983), paraventricular nucleus (Swanson and Sawchenko, 1983; Jones and Yang, 1985), caudal raphe (Hermann et al., 1997), and rostroventrolateral medulla (Van Bockstaele et al., 1989).

LC is innervated by fibers that contain many neurotransmitters such as opiates, glutamate, gamma-aminobutyric acid (GABA), serotonin, epinephrine, and the peptide orexin/hypocretin (AstonJones et al., 1995). The nucleus paragigantocellularis lateralis (PGi) is a source for glutamate, GABA, enkephalin, corticotrophin releasing hormone $(\mathrm{CRH})$, and epinephrine. A strongly inhibitory GABA and enkephalin input originates from the dorsomedial rostral medulla, whereas orexin/hypocretin inputs originate in the hypothalamus (Horvath et al., 1999), as do histaminergic inputs (Pollard et al., 1978).

Because of these widespread projections, LC is implicated in the control of many physiological functions, including control of respiration (Oyamada et al., 1998; Fabris et al., 1999; Hilaire et al., 2004; Putnam et al., 2004; Viemari et al., 2004; Biancardi et al., 2008; de Carvalho et al., 2010; de Souza Moreno et al., 2010; Gargaglioni et al., 2010; Biancardi et al., 2014; Patrone et al., 2014) and cardiovascular function (Sved and Felsten, 1987; Yao and 
Lawrence, 2005; Biancardi et al., 2014; Patrone et al., 2014). LC is considered a central $\mathrm{CO}_{2} / \mathrm{pH}$ chemoreceptor site in amphibians and mammals (Noronha-de-Souza et al., 2006; Gargaglioni et al., 2010; Santin and Hartzler, 2013) and more than $80 \%$ of its neurons are chemosensitive, responding to hypercapnia with an increased firing rate (Pineda and Aghajanian, 1997; Oyamada et al., 1998; Filosa et al., 2002). Local acidification of noradrenergic LC neurons increases respiratory frequency and phrenic nerve discharge in cats (Coates et al., 1993). Lesion of approximately $80 \%$ of noradrenergic neurons of LC by using 6-OHDA elicited a large decrease in the response to $\mathrm{CO}_{2}$, of approximately $64 \%$, due to a decreased tidal volume $\left(\mathrm{V}_{\mathrm{T}}\right)$, indicating that this nucleus exerts a profound effect on the hypercapnic ventilatory response (Biancardi et al., 2008). The objective of this review is to summarize the available data on the role of chemical and electrical neurotransmission in the $\mathrm{LC}$ in the control of ventilation during $\mathrm{CO}_{2}$ challenge.

\section{ELECTRICAL MODULATION OF THE LC}

The traditional concept of cell communication is based on the presumption that the electrical coupling was a "primitive" form of signaling commonly present in invertebrates, since the chemical synapses are characterized as the predominant form of intercellular signaling in the CNS of vertebrates (Naus and Bani-Yaghoub, 1998). However, studies have shown that electrical coupling appears to be an important signaling mechanism for several functions, including cardiorespiratory regulation. In this regard, electrical communication is present in regions of the CNS involved in the generation and modulation of respiratory rhythm, inspiratory motoneuron synchronization, central chemoreception and cardiovascular control (Davidson and Baumgarten, 1988; Nattie, 1999; Solomon etal., 2001; Solomon, 2003; Rash et al., 2007; Pierce etal., 2010). In fact, the presence of gap junctions has been reported in many regions that are considered $\mathrm{CO}_{2} / \mathrm{pH}$ chemosensitive such as the caudal medullary raphe, retrotrapezoid nucleus (RTN), dorsal motor nucleus of the vagus (DMV), nucleus of the solitary tract (NTS), and the LC, thus implying that electrical coupling may constitute an important mechanism for $\mathrm{CO}_{2}$ drive to breathe (Dean et al., 1997; Rekling and Feldman, 1997; Solomon et al., 2000; Dean et al., 2001, 2002; Solomon and Dean, 2002).

Gap junctions are formed by proteins that create intercellular channels; these transmembrane pores facilitate the direct exchange of small molecules, metabolites, adenosine triphosphate (ATP) and ions between cells in direct contact (Hooper and Subak-Sharpe, 1981; Loewenstein, 1981; Picoli et al., 2012). These channels are composed by a combination of two hemichannels (connexons), each connexon containing a group of six proteins called connexins $(\mathrm{Cx})$. These proteins fold in a hexameric structure creating a hydrophilic channel that connects the cytosol of neighboring cells (Davidson and Baumgarten, 1988; Solomon and Dean, 2002; Picoli et al., 2012).

Cells that communicate via electrical synapses, in most cases, express more than one Cx isoform (Solomon and Dean, 2002), thus each connexon may consist of a single or multiple isoforms of Cxs (homomeric or heteromeric connexons, respectively; Bruzzone et al., 1996; Kumar and Gilula, 1996; Laird, 2006). The physiological properties of the gap junction depend on the protein isoforms that are present in the connexon (Kumar and Gilula, 1996; Bruzzone and Ressot, 1997), which can explain the differences in sensitivity to intracellular $\mathrm{pH}(\mathrm{pHi})$, intracellular calcium and phosphorylation (Goodenough et al., 1996). Among the 15 connexin isoforms identified in the CNS of adult and newborn rats (Beyer et al., 1990; Dermietzel and Spray, 1993; Bruzzone et al., 1996; Dahl, 1996; Condorelli et al., 1998), Cxs 26, 32, and 36 are the most abundantly expressed in neuronal cells (Dermietzel et al., 1989; Belliveau et al., 1991; Belliveau and Naus, 1995; Condorelli et al., 1998; Solomon et al., 2001).

A striking characteristic of the LC neurons is the cell-to-cell coupling via gap junctions (Christie etal., 1989; Christie and Jelinek, 1993; Travagli et al., 1995; Ishimatsu and Williams, 1996; Oyamada et al., 1999; Alvarez-Maubecin et al., 2000; Ballantyne and Scheid, 2000). The cellular coupling facilitates the communication between neurons and it is important to coordinate the firing of the LC neurons, since it seems that the entire nucleus fires simultaneously in response to sensory inputs (Nestler et al., 1999). In fact, this synchronism is important for increase of NA release from LC neurons (Christie et al., 1989; Travagli et al., 1995; Ishimatsu and Williams, 1996; Alvarez-Maubecin et al., 2000). According to Rash etal. (2007), the LC neurons of adult rats express $\mathrm{Cx} 32$ and $\mathrm{Cx} 36$, while the presence of $\mathrm{Cx} 26$, an isoform which is sensitive to $\mathrm{CO}_{2}$, is still controversial topic in the field (Alvarez-Maubecin et al., 2000). Previous studies have shown that Cx36 expression in the CNS increases during the first week of life and reduces in adults (Sohl et al., 1998; Belluardo et al., 2000; Solomon, 2003). This Cx participates in the astrocytic and neuronal differentiation during development (Hartfield et al., 2011) and also plays an important role in learning and memory consolidation (Frisch et al., 2005). Regarding Cx32, this isoform is only detected between 5 and 10 days postnatal (Dermietzel et al., 1989; Belliveau et al., 1991; Belliveau and Naus, 1995; Nadarajah et al., 1997; Solomon et al., 2001) and is hypothesized to participate in central $\mathrm{CO}_{2}$ chemoreception (Solomon et al., 2001). Further studies are needed to clarify the role of $\mathrm{Cx} 36$ and $\mathrm{Cx} 32$ in the LC.

Oyamada et al. (1998) demonstrated that transversal brainstem slices of newborn rats presented $83 \%$ of LC neurons being modulated by the respiratory rhythm and this modulation depends on the activation of an excitatory amino acid pathway. Also there are evidences that LC neurons exhibit spontaneous depolarizations that do not depend on the chemical synaptic transmission (Williams and Marshall, 1987; Dean et al., 2001) and this electrical synchronization is interrupted when a gap junction blocker is administered (Christie et al., 1989; Travagli et al., 1995; Ishimatsu and Williams, 1996; Oyamada et al., 1999; Alvarez-Maubecin et al., 2000; Ballantyne and Scheid, 2000; Andrzejewski et al., 2001; Ballantyne et al., 2004), reinforcing the role of the electrical coupling in the maintenance of endogenous rhythmic activity of LC neurons (Hayashida et al., 2010).

Recently, Nichols et al. (2008) demonstrated using newborn brainstem slices that carbenoxolone (CARB, a gap junction blocker) decreases the percentage of LC neurons that are responsive to $\mathrm{CO}_{2}$, as well as the magnitude of this response (chemosensitivity index - CI) during postnatal development. In addition, 
Rash et al. (2007) reported that LC neurons are strongly electrically coupled during early post-natal development, suggesting that gap junctions may play an important role in the chemosensitive response of LC neurons during development. However, the function of gap junctions may differ among other chemosensitive nuclei, since the synaptic blockade of NTS neurons by CARB perfusion reduces the ventilatory response to hypercapnia in 710 week-old awake rats but not in $>10$-week-old rats (Parisian et al., 2004). In the RTN, CARB perfusion decreases the ventilatory response to $\mathrm{CO}_{2}$ in younger animals, but increases the hypercapnic ventilatory response in older animals (Hewitt et al., 2004).

The pattern of development regarding the ventilatory response to $\mathrm{CO}_{2}$, present a clear and important change in the ventilatory response to hypercapnia during the neonatal period in rats, especially when comparing young versus older animals (Putnam,2001). The LC of rats younger than 10 days (P10) has a high percentage of chemosensitive neurons (70$80 \%$ ) and the magnitude of the response to hypercapnia is high (approximately 235\%) compared with older neonates (125\%; Hartzler etal., 2007). Additionally, the percentage of LC neurons and the $\mathrm{CI}$ is not affected by CARB in rats younger than P10 (Hartzler etal., 2007; Nichols etal., 2008). On the other hand, the $\mathrm{CO}_{2}$ chemosensitive response of LC neurons of older neonates $(>\mathrm{P} 10)$ is reduced by $20 \%$ in the presence of CARB, without affecting the $\mathrm{CI}$, suggesting that the electrical coupling increases the responsiveness to $\mathrm{CO}_{2}$ of $\mathrm{LC}$ neurons in newborn rats (Hartzler et al., 2007; Nichols et al., 2008; Gargaglioni et al., 2010).

A recent study by our group investigated the participation of gap junctions in the $\mathrm{CO}_{2}$ ventilatory response in unanesthetized adult rats by bilaterally microinjecting CARB into the LC of Wistar rats (Patrone et al., 2014). During normocapnic conditions, the gap junctions have no regulatory role on ventilation, since CARB microinjection did not change the resting ventilation (Patrone et al., 2014). Regarding hypercapnic ventilatory response, our findings corroborate the literature since CARB (1 $\mathrm{mM}$ or $3 \mathrm{mM}$ ) microinjection into LC neurons resulted in a significant reduction, approximately 24 and 20\%, respectively, in the ventilatory response to $7 \% \mathrm{CO}_{2}$. This result was confirmed by the lower slopes of the 1 and $3 \mathrm{mM} \mathrm{CARB} \mathrm{CO}_{2}$ sensitivity curves compared to the curve for vehicle-injected rats (Figure 1). Therefore, our data suggest that gap junctions in the LC are important for modulation of the $\mathrm{CO}_{2}$ drive to breathe in adult rats.

Recent studies have also addressed whether LC electrical synapses are involved in cardiovascular regulation. Microinjection of CARB in LC did not affect cardiovascular parameters during normocapnia, suggesting that gap junctions in LC neurons are unlikely to play a role in the tonic control of cardiovascular function. However, heart rate decreased after $\mathrm{CO}_{2}$ exposure in the group treated with $3 \mathrm{mM} \mathrm{CARB}$, indicating a possible role of LC neuronal gap junctions in the regulation of heart rate during $\mathrm{CO}_{2}$ challenge. Summarizing, electrical synapses in LC neurons, specifically through gap junctions, play a role in the $\mathrm{CO}_{2}$ drive to breathe and also modulate heart rate under hypercapnic conditions.

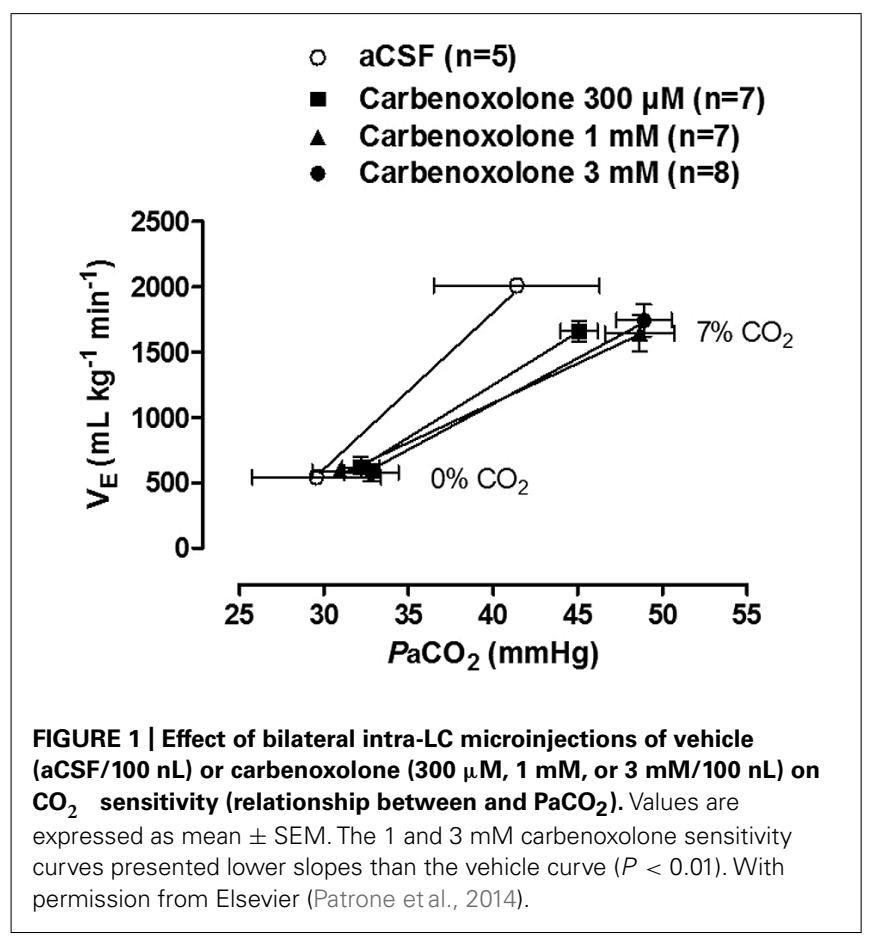

\section{NEUROCHEMICAL MODULATION OF THE LC GLUTAMATE}

Glutamate is an endogenous amino acid that acts as a major excitatory neurotransmitter in the mammalian CNS (Ruggiero et al., 2011) and participates in the central generation and transmission of respiratory rhythm (Bonham, 1995). Glutamate receptors are divided into two subtypes, ionotropic and metabotropic. Ionotropic receptors can be further divided in NMDA (N-methylD-aspartate) and non-NMDA (AMPA and Kainate). The NMDA receptors bind simultaneously with glutamate and glycine, resulting in the influx of $\mathrm{Na}^{+}$and $\mathrm{Ca}^{2+}$, whereas the non-NMDA receptors are more rapidly depolarized, causing a $\mathrm{Na}^{+}$influx (Bowie, 2008). The metabotropic receptors are G-protein coupled, and they can be divided in mGlu I, II, and III. These receptors appear to be related with presynaptic regulation, and they also modulate the transmission of the respiratory rhythm to phrenic motoneurons; however, they are not involved in respiratory rhythmogenesis (Liu et al., 1990).

Glutamate is a primary excitatory neurotransmitter in the LC (Singewald and Philippu, 1998), and several studies identified different subunits of ionotropic glutamate receptors, with the majority belonging to the non-NMDA category (Sato et al., 1993; Wisden and Seeburg, 1993; Petralia et al., 1994). Experiments using anesthetized rabbits demonstrated that activation of LC neurons with L-glutamate increased the respiratory frequency and discharge rate of the phrenic nerve, while decreasing duration of inspiration and expiration (Li et al., 1992).

The major glutamatergic afferents to the LC come from the lateral nucleus paragigantocellularis (Ennis et al., 1992). Another important source of glutamate inputs are neurons localized in the lateral hypothalamus, which are also responsible for producing orexin (Peyron et al., 1998). A previous study performed by Henny 
et al. (2010) demonstrated that a subset of orexinergic terminals have the ability to release glutamate in addition to orexin, and do play a role in postsynaptic targets via glutamatergic synapses, including terminals in the LC. More recently, it was demonstrated that catecholaminergic neurons of the rostral ventrolateral medulla (RVLM), most likely C1 neurons, establish a glutamatergic synapse with LC (Holloway et al., 2013). LC noradrenergic neurons are important for wake-promoting systems; therefore, glutamatergic signaling and LC neurons could be important to the state-dependent control of breathing (Gonzalez and Aston-Jones, 2006).

Recently, we have investigated the role of glutamatergic inputs in the LC modulation of the ventilatory response to hypercapnia in unanesthetized rats by applying Kynurenic Acid (KY, an antagonist at ionotropic glutamate receptors) or $\alpha$-methyl4-carboxyphenylglycine (MCPG, an antagonist at metabotropic glutamate receptors; Taxini et al., 2013). Microinjections of MCPG did not affect cardiorespiratory responses during normocapnia or hypercapnia. Remarkably, microinjection of $\mathrm{KY}$ into the LC amplified pulmonary ventilation during $7 \% \mathrm{CO}_{2}$, indicating that glutamatergic inputs on LC neurons cause an inhibition of the hypercapnia-induced hyperpnea. Our results are comparable to previous evidence in the literature that glutamate acts on ionotropic glutamatergic receptors in the LC and RVLM, thus inhibiting the ventilatory response to hypoxia (Dillon et al., 1991; Ferreira et al., 2004). Despite the fact that glutamate is classically known as an excitatory neurotransmitter in the CNS, there is also evidence that glutamate acts on NMDA receptors exerting a "functionally inhibitory" role, by suppressing circuit-level neural activity through the activation of GABAergic interneurons (Fitzgerald, 2012). Thus, inhibition of NMDA receptors by antagonist drugs may activate GABAergic neurotransmission as observed in rat prefrontal cortex (Homayoun and Moghaddam, 2007). Presumably, the increased ventilatory response to $\mathrm{CO}_{2}$ after NMDA blockade could be linked to inhibition of inhibitory interneurons presents in the LC, which accounts for approximately $8 \%$ of LC neurons (Iijima and Ohtomo, 1988; de Carvalho et al., 2010). A second possible explanation is that the projections from the LC to the central respiratory pattern generator, or directly to the respiratory premotoneurons, may be mediated by LC GABAergic neurons (Figure 2). Therefore, the attenuation of the hypercapnic ventilator response, mediated by LC ionotropic receptors, can be the result of excitatory projections to glycinergic Bötzinger (BÖTZ) neurons, which participates in the termination of inspiration (Champagnat et al., 1982; Bonham, 1995; Schreihofer et al., 1999). Thus, a possible role of LC glutamatergic mechanisms could be in limiting the extent of hypercapnia-induced hyperpnea. However, the interaction between the LC neurons and the glycinergic BÖTZ neurons is still unclear.

With respect to cardiovascular regulation, glutamatergic receptor antagonism did not affect blood pressure and heart rate during normocapnia and hypercapnia, supporting previous findings which demonstrate that the inhibition of LC neurons (Sved and Felsten, 1987; Miyawaki et al., 1991) or electrolytic lesions of this nucleus (Anselmo-Franci et al., 1998) have no effect on cardiovascular parameters.

\section{SEROTONIN}

Serotonin (5-hydroxytryptamine, 5-HT) is a neurotransmitter involved in many physiological functions such as the sleep-wake cycle, mood, appetite, and neurovegetative control. Serotonin can also be linked to emotional disorders such as anxiety and depression (Jacobs and Azmitia, 1992; Brown and Gershon, 1993; Jouvet, 1999; Saper et al., 2001; Jones, 2005). Serotoninergic neurons are located mainly in the raphe nuclei and project to almost all brain areas and the spinal cord (Törk, 1990; Baumgarten and Göthert, 1997).

Extensive reciprocal projections are reported between raphe and LC neurons (Pasquier etal., 1977; Pickel etal., 1977; Cedarbaum and Aghajanian, 1978; Morgane and Jacobs, 1979; Baraban and Aghajanian, 1981; Vertes and Kocsis, 1994; Luppi et al., 1995; Peyron etal., 1996; Kim et al., 2004). In fact, LC neurons receive dense serotonergic projections coming mostly from dorsal raphe (DR) and pericoerulear 5-HT neurons (AstonJones et al., 1991a; Kaehler et al., 1999; Kim etal., 2004), and these projections are important for controlling sleep-wake cycle, vigilance, analgesia, cognition, depression, pain and anxiety (Redmond and Huang, 1979; Segal, 1979; Charney and Redmond, 1983; Uhde etal., 1984; Mokha et al., 1985; Meltzer and Lowy, 1987; Seiver, 1987; Kim et al., 2004). Stimulation of central 5-HT neurons causes reductions in the LC spontaneous and painevoked activity (Segal, 1979) and 5-HT, when applied in the LC, attenuates the excitatory responses of this nucleus to sensorial, neurochemical and electrical stimuli (Bobker and Williams, 1989; Aston-Jones et al., 1991a).

Administration of the 5- $\mathrm{HT}_{1 \mathrm{~A}}$ receptor antagonist WAY-100635 in anesthetized rats suppressed LC activity. Interestingly, this effect can be prevented by lesioning central 5-HT neurons (injection of 5,7 DHT intracerebroventricularly) or by $5-\mathrm{HT}_{2}$ receptor antagonism, indicating that the suppressant effect of WAY-100635 on noradrenergic neuron firing is dependent on intact 5-HT neurons and also involves an over-activation of excitatory $5-\mathrm{HT}_{2}$ receptors in inhibitory neurons projecting to LC (Haddjeri et al., 1997; Szabo and Blier, 2001).

Recently, we have demonstrated that hypercapnia induces an increase in 5-hydroxyindole-3-acetic acid (5-HIAA) levels and serotonergic turnover (5-HTTIA/5-HT ratio) in the LC of rats (de Souza Moreno et al., 2010). In this study, we also microinjected WAY-100635, Ketanserin (5- $\mathrm{HT}_{2 \mathrm{~A}}$ antagonist), or DOI (5- $\mathrm{HT}_{2 \mathrm{~A}}$ agonist) into the $\mathrm{LC}$ of unanesthetized rats to verify the role of 5-HT receptors in the $\mathrm{CO}_{2}$ ventilatory response. Antagonism of 5-HT receptors in the LC had no effect on resting breathing parameters (de Souza Moreno etal., 2010). Microinjection of WAY-100635 into the LC decreased the ventilatory response to $\mathrm{CO}_{2}$, possibly due to inhibition of noradrenergic neurons. The reduction of the response to $\mathrm{CO}_{2}$ by WAY-100635 may be due to its direct antagonism of presynaptic $5-\mathrm{HT}_{1 \mathrm{~A}}$ receptors, leading to an increase in 5-HT release and consequential activation of postsynaptic $5-\mathrm{HT}_{2 \mathrm{~A}}$ receptors in the LC.

Another possible explanation for our results is that WAY100635 may decrease the glutamate evoked activation of LC neurons. In this regard, Aston-Jones et al. (1991a) has previously demonstrated that 5-HT decreased glutamate evoked activation 
A

\section{CPG/ premotoneurons/ glycinergic BÖTZ neurons}

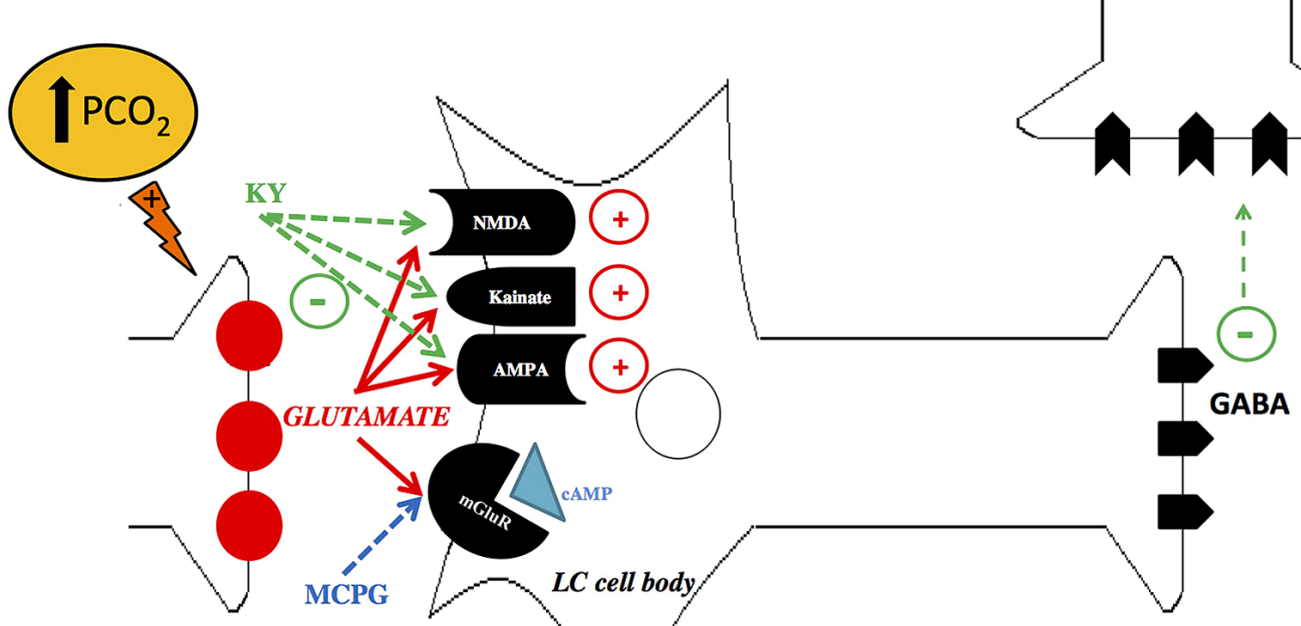

Presynaptic terminal
LC terminal

B

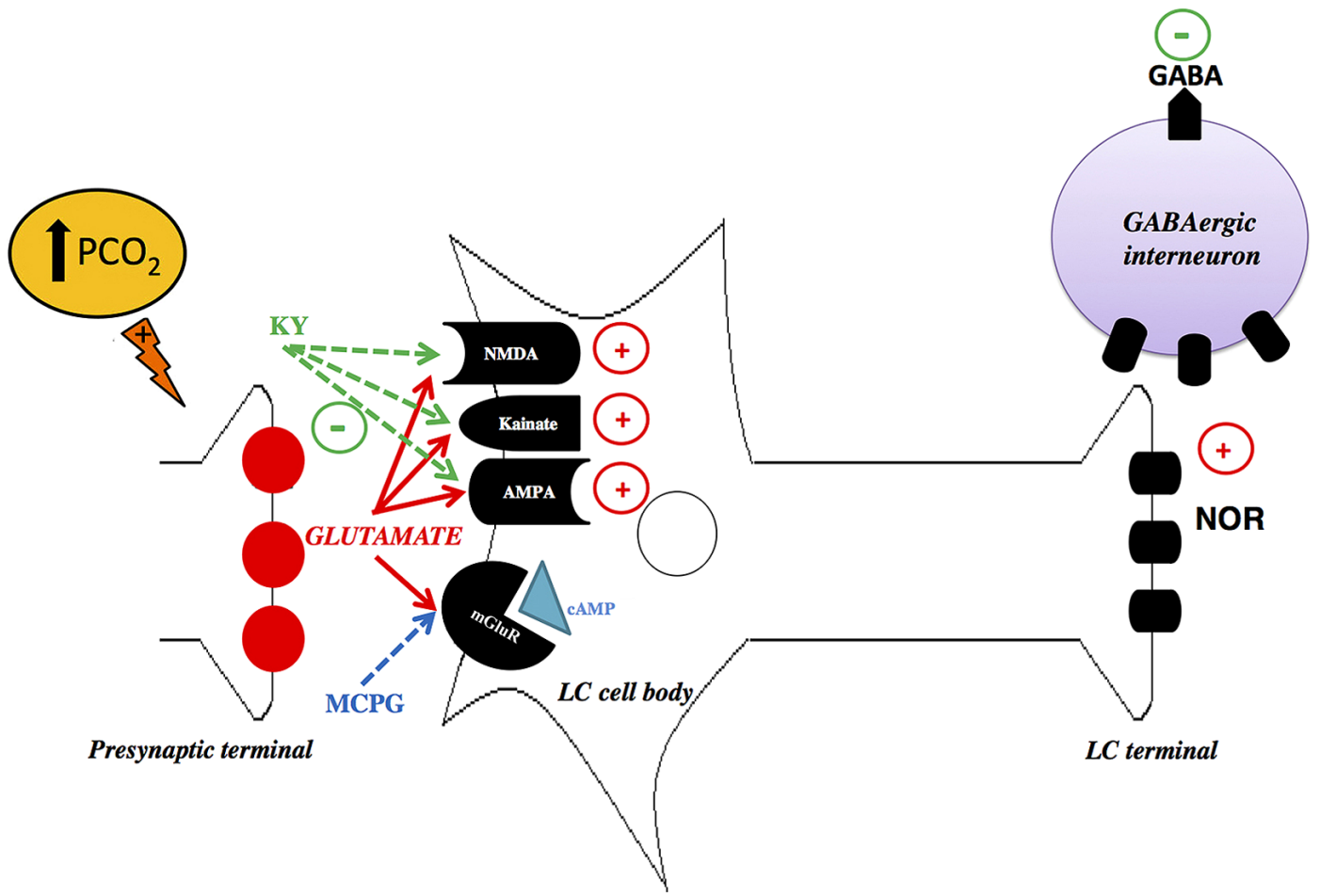

FIGURE 2 | Schematic drawings depicting possible mechanisms of glutamatergic signaling in the locus coeruleus (LC). (A) Hypercapnia increases glutamate release in the LC, which directly activates LC gabaergic neurons. Inhibition of NMDA, AMPA, and Kainate receptors by KY may inhibit LC GABAergic neurons, which project to the central respiratory pattern generator (CPG), or directly to the respiratory premotoneurons, causing an increase in the activity of these neurons, promoting an increase in ventilation. (B) Another possibility is that hypercapnia increases glutamate release in the LC, which possibly activates noradrenergic neurons that induce GABA release. Inhibition of NMDA, AMPA and Kainate receptors by KY may decrease the release of excitatory neurotransmitter of LC, probably noradrenaline (NOR), leading to inhibition of GABAergic interneuron, which in turn may reduce the activation of the glycinergic Bötzinger (BÖTZ) neurons, causing an increase in the hypercapnic ventilatory response. LC, locus coeruleus; PGC, nucleus paragigantocellularis; $K Y$, kynurenic acid; $M C P G$, $\alpha$-methyl-4-carboxyphenylglycine. With permission from Wiley Online Library (Taxini etal., 2013). 
of LC cells using extracellular recordings from single neurons in an anesthetized preparation. Moreover, Bobker and Williams (1989) showed that the receptors mediating this inhibition are the $5-\mathrm{HT}_{1 \mathrm{~A}}$ and $5-\mathrm{HT}_{1 \mathrm{~B}}$ subtypes, probably located presynaptically in the PGi terminals, since LC receives afferent excitatory glutamatergic inputs from the PGi nucleus (Ennis and Aston-Jones, 1987). Therefore, this interaction between glutamate and 5-HT may play a role in preventing a strong inhibition of LC during hypercapnia.

In fact, microinjections of Ketanserin in the LC increased the hypercapnic hyperpnea, whereas the $5-\mathrm{HT}_{2 \mathrm{~A}}$ receptor agonist DOI evoked an opposite effect. Therefore, we suggested that release of 5-HT is increased in the LC during $\mathrm{CO}_{2}$ challenge and that 5-HT negatively modulates the LC stimulatory role in the hypercapnic ventilatory response, probably acting through postsynaptic $5-\mathrm{HT}_{2 \mathrm{~A}}$ receptors or presynaptic $5-\mathrm{HT}_{2 \mathrm{~A}}$ in GABAergic terminals. The possible action of 5-HT on GABAergic terminals corroborates previous study that reported that $\mathrm{GABA}_{\mathrm{A}}$ receptor antagonist bicuculline on LC neurons blocked the inhibitory effects of intravenously injected DOI on LC firing (Chiang and Aston-Jones, 1993).

\section{ATP}

ATP is an important intracellular energy source for all cells and is present in all mammalian neurons (Edwards and Gibb, 1993). Burnstock (1972) proposed the concept of purinergic signaling, after the observation that a purine nucleotide could act as a neurotransmitter in non-adrenergic, non-cholinergic (NANC) nerves supplying the gut and urinary bladder. Currently, it is established that ATP acts as a sole neuromodulator or is co-released with other neuromodulators in the peripheral and in the CNS (Abbracchio et al., 2009).

In the CNS, ATP acts on regions involved in cardiovascular and respiratory regulation, including the LC (Thomas and Spyer, 2000; Thomas et al., 2001; Gourine et al., 2002, 2005; Antunes et al., 2005; Yao and Lawrence, 2005). LC neurons are of particular interest as purinergic signaling targets because ATP can act as a neuromodulator on neurons terminating within the LC or as a cotransmitter of recurrent axonal collaterals or dendrites of intrinsic LC neurons (Tschöpl et al., 1992; Nieber et al., 1997; Poelchen et al., 2001). Poelchen et al. (2001) reported for the first time that ATP and NA are co-released from recurrent axon collaterals onto LC neurons producing biphasic synaptic potentials consisting of early depolarizing (epsp = excitatory postsynaptic potential) and late hyperpolarizing (ipsp = inhibitory postsynaptic potential) components, respectively.

P2 purinergic receptors are activated by ATP (Burnstock, 1997) and are classified into P2X (ligand-activated cationic channel, ionotropic receptor) and P2Y (G-protein-coupled receptor, metabotropic receptor) subtypes (Abbracchio and Burnstock, 1994; Fredholm et al., 1994; Mateo et al., 1998). The LC contains more $\mathrm{P} 2 \mathrm{X}$ receptors, and the $\mathrm{P} 2 \mathrm{X}$ population consists mainly of the P2X2, P2X3, and P2X6 subtypes (Yao et al., 2000). Although $\mathrm{P} 2 \mathrm{X} 7$ receptors have been found in LC area and it appeared that these receptors are located in astrocytes (Khakpay et al., 2010). A short stimulation of the $\mathrm{P} 2 \mathrm{X} 7$ receptors leads to activation of cationic currents as the other subtypes of $\mathrm{P} 2 \mathrm{X}$ receptors although a repeated or prolonged ATP exposure also opens a large pore which allows the passage of organic cations and dye molecules (Virginio et al., 1999).

ATP evokes the release of NA (Poelchen et al., 2001) and ATP within LC, when acting on presynaptic P2X receptors (Boehm, 1999), and inhibits the release of NA and ATP, when acting on presynaptic P2Y receptors (von Kügelgen et al., 1994, 1995; Poelchen et al., 2001). In LC neurons, activity of NA on postsynaptic $\alpha 2$-adrenoceptors has been shown to mediate hyperpolarization (Aghajanian and Vandermaelen, 1982; Poelchen et al., 2001), while activation of both P2X and P2Y receptors by ATP has been shown to depolarize LC neurons (Harms et al., 1992; Shen and North, 1993; Scheibler et al., 2004). Thus, ATP may be released to provide an excitatory counterbalance to the inhibitory noradrenergic drive of these neurons (Illes et al., 1994).

There is evidence that tyrosine hydroxylase (TH) co-localizes with $\mathrm{P} 2 \mathrm{X}$ receptors in the $\mathrm{LC}$ (Yao et al., 2000) indicating the presence of $\mathrm{P} 2 \mathrm{X}$ receptors in LC noradrenergic neurons. Moreover, $\alpha, \beta$-meATP (a P2X receptor agonist) excites LC neurons in in vitro preparations of the pons (Tschöpl et al., 1992; Shen and North, 1993), increasing the frequency of spontaneous action potentials in LC (Tschöpl et al., 1992).

On the other hand, Kuwahata (2004) demonstrated that ATP produced a hyperpolarizing response or a transient hyperpolarizing response that preceded the depolarization in LC neurons. However, AMP-PNP (adenosine $5^{\prime}$ - $(\beta, \gamma$-imido) triphosphate, which is more resistant to dephosphorylation than ATP, only depolarizes LC neurons. According to Kuwahata (2004) adenosine is the likely source of the ATP-induced hyperpolarizing response in LC neurons.

Despite the excitatory effects of ATP in LC neurons, little is known about the physiological consequences of ATP when administered in the LC in vivo, with antinociception being an exception (Fukui et al., 2004). A recent study by our group focused on the role of ATP in the cardiorespiratory control through P2 receptor-mediated mechanisms in the LC of unanesthetized rats (Biancardi etal., 2014). In this study we provided the first functional evidence that purinergic neuromodulation within the LC is important for cardiorespiratory control in unanesthetized animals. In normocapnic conditions, ATP release within the LC may occur to maintain respiratory frequency (Biancardi et al., 2014). We observed that PPADS (ATP antagonist with predominant actions on $\mathrm{P} 2 \mathrm{X}$ receptors) decreased respiratory frequency, whereas suramin (P2 nonselective antagonist) did not change any of the investigated respiratory variables (Biancardi et al., 2014), when injected into the LC.

Microinjections of ATP and the $\mathrm{P} 2 \mathrm{X}$ receptor agonist $\alpha, \beta$ meATP into brainstem respiratory nuclei, such as the nucleus tractus solitarius (NTS) and RVLM, also cause changes in respiratory amplitude and frequency (Thomas et al., 2001; Antunes et al., 2005). Several studies have shown that hypercapnia triggers ATP release in the RVLM (for review see Gourine et al., 2005). The injection of $\mathrm{P} 2 \mathrm{X}$ receptor antagonists in this region reduces the ventilatory response to hypercapnia, indicating that ATP, acting on $\mathrm{P} 2 \mathrm{X}$ receptors, plays a critical role in the chemoreception to $\mathrm{CO}_{2} / \mathrm{pH}$ (Thomas and Spyer, 2000; Gourine et al., 2005). 
Biancardi et al. (2008) also observed that the ablation of about $80 \%$ of LC noradrenergic neurons was associated with a large decrease $(64 \%)$ in the ventilatory response to increased $\mathrm{CO}_{2}$. More recently, we observed that microinjections of $\alpha, \beta$-meATP into the LC promoted a greater increase in ventilation during the hypercapnic challenge $\left(7 \% \mathrm{CO}_{2}\right)$, compared with the controls (Biancardi et al., 2014). This was blocked by pretreatment with PPADS, indicating that $\alpha, \beta$-meATP is acting on $\mathrm{P} 2 \mathrm{X}$ receptors to evoke that effect. Thus, LC purinergic signaling appears to play a role in the $\mathrm{CO}_{2}$ drive to breathe, specifically through the activation of $\mathrm{P} 2$ receptors, accelerating the ventilatory response to hypercapnia. This observation was probably due to $\mathrm{P} 2 \mathrm{X}$ activation of noradrenergic neurons, triggering further NA and ATP release which in turn activate rhythm-generating circuits and medullary respiratory neurons in one or more of the following brainstem nuclei: RTN, RVLM, prepositus hypoglossi nucleus, and NTS (Aston-Jones et al., 1986, 1991b; Astier et al., 1990; Pieribone and Aston-Jones, 1991; Vulchanova et al., 1997; Llewellyn-Smith and Burnstock, 1998; Kanjhan et al., 1999; Thomas and Spyer, 2000; Yao et al., 2000; Gourine et al., 2003; Lorier et al., 2007, 2008; Huxtable et al., 2009).
Unexpectedly, suramin induced an increase in ventilation during $\mathrm{CO}_{2}$ exposure. However, this effect occurred $20 \mathrm{~min}$ after the microinjections, while the effect of the P2X agonist appeared only $2 \mathrm{~min}$ after microinjections. These observations suggest that suramin may be acting on presynaptic P2Y receptors, which, due to location and metabotropic mechanism of activation, may introduce a delay in the response. Given that these receptors are G-protein coupled (Abbracchio and Burnstock, 1994), the latency to induce neurotransmitter release is prolonged.

Yao and Lawrence (2005) suggested that ATP modulates the cardiovascular system via activation of $\mathrm{P} 2 \mathrm{X}$ receptors in the LC of anesthetized rats. Moreover, they hypothesize that purinergic and noradrenergic systems are tonically active within the LC and interact functionally. They also demonstrated that microinjections of a P2X receptor agonist into the $\mathrm{LC}$ induced hypotension and bradycardia in anesthetized animals. Conversely, microinjections of $\mathrm{P} 2$ receptor antagonists induced hypertension and tachycardia. In another study, Biancardi et al. (2014) evaluated the role of ATP in the modulation of cardiovascular responses to $\mathrm{CO}_{2}$ exposure. They observed that both PPADS and suramin induced an increase

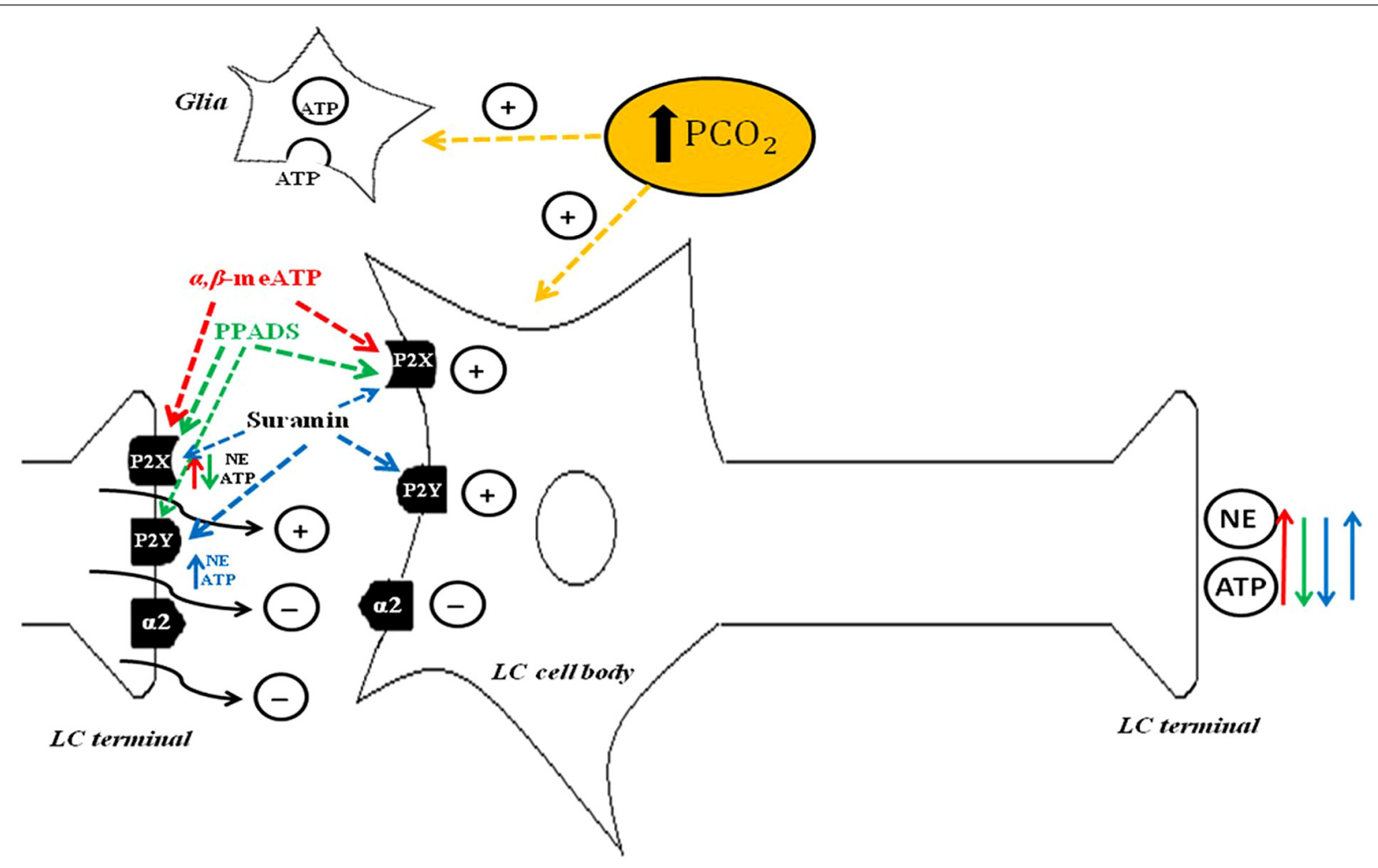

FIGURE 3 | Schematic drawing depicting possible mechanisms of purinergic signaling in the locus coeruleus (LC). ATP induces depolarization of noradrenergic neurons through P2X and P2Y postsynaptic receptors (Harms etal., 1992; Shen and North, 1993), NE and ATP release through P2X presynaptic receptors (Boehm, 1999) and inhibition of NE and ATP release through P2Y presynaptic receptors (von Kügelgen etal., 1994, 1995; Poelchen etal., 2001). $\alpha, \beta$-meATP agonism of P2X presynaptic receptors may promote NE and ATP release, whereas agonism of $\mathrm{P} 2 \mathrm{X}$ postsynaptic receptors may activate noradrenergic neurons to further increase NE and ATP release (red arrow, Nieber etal.,
1997). PPADS blocks mainly P2X receptors, which reduces NE and ATP release at LC terminals (green arrow). Suramin blocks P2X and P2Y receptors. The postsynaptic receptors reduce neurotransmitter release (blue down arrow). The presynaptic P2Y receptor subtype increases NE and ATP release, thereby further activating noradrenergic neurons and causing additional NE and ATP release (blue up arrow). $\mathrm{PCO}_{2}$ increase in the cerebrospinal fluid activates LC noradrenergic neurons (yellow arrow; Biancardi etal., 2008) and astrocytes (yellow arrow; Alvarez-Maubecin etal., 2000; Spyer etal., 2004) which, in turn, release ATP. With permission from Wiley Online Library (Biancardi etal., 2014). 
in mean arterial pressure (MAP) under hypercapnic conditions, although $\alpha, \beta$-MeATP did not change cardiovascular parameters in unanesthetized animals. This increase in MAP may be due to a blockade of $\mathrm{P} 2 \mathrm{X}$ and $\mathrm{P} 2 \mathrm{Y}$ postsynaptic receptors, which may attenuate depolarization of LC noradrenergic neurons, thereby reducing NA release. A decrease in NA, in turn, decreases RVLM inhibition and promotes pressor response.

Figure 3 depicts proposed LC purinergic neuromodulation mechanisms based on Biancardi et al. (2014) and evidence from Williams etal. (1985), Aghajanian and Wang (1986), Harms et al. (1992), Shen and North (1993), von Kügelgen et al. (1994), von Kügelgen et al. (1995), Nieber et al. (1997), Boehm (1999), Alvarez-Maubecin et al. (2000), Poelchen et al. (2001), Spyer et al. (2004), and Biancardi et al. (2008).

Until recently, there were no studies available in the literature regarding ATP-mediated respiration mechanisms in the LC. However, a recent study from our group (Biancardi et al., 2014) introduced the idea of the participation of purinergic signaling in the LC in the modulation of respiration. Further investigation is needed, nevertheless, to address how hypercapnic challenges modulate purinergic signaling within the LC. An increase in arterial blood $\mathrm{PCO}_{2}$ triggers immediate ATP release from ventral chemosensory site(s) on the surface of the medulla, and glial cells appear to be the likely source of this ATP release in response to such stimuli (Gourine etal., 2005). The striking abundance of astrocytes in the LC (Alvarez-Maubecin et al., 2000) supports the idea that these cells may play a distinctive role in that nucleus. Based on the reviewed literature, we believe that the field would benefit greatly from further investigation of the possibility that hypercapnic exposure induces ATP release from LC astrocytes, which contribute to modulation of respiratory activity.

\section{CONCLUSION}

We have reviewed evidence that LC neurons exert an important role in hypercapnic ventilatory response, and this response is chemically modulated by $5-\mathrm{HT}$, glutamate, ATP and electrically controlled by GAP junctions. As it is well known, LC is an important pontine group that has access to respiration-related cell groups in the caudal brainstem, and also modulates the sleep wake-cycle and many other homeostatic function. Therefore, this nucleus can be considered a gateway to adjust respiration to sleep-wake events. In addition, LC has been linked to pathological conditions such as Rett syndrome, where individuals present decreased $\mathrm{CO}_{2}$ chemosensitivity. This CNS dysfunction is characterized by the loss of function mutations in the X-linked gene encoding in Methyl-CpG-binding protein-2 (MeCP2; Amir et al., 1999). MeCP2 knockout mice presents morphological (decreased soma size), electrical (reduced membrane conductance and strong afterhyperpolarization amplitude), and neurochemical (reduced TH content) alterations of LC neurons (Taneja et al., 2009). However, the neurobiological mechanisms underlying such breathing disorders presented by people with Rett syndrome are still unclear. According to Taneja et al. (2009), LC is a critical site at which loss of $\mathrm{MeCP} 2$ results in CNS dysfunction and restoration of normal LC function may attenuate the symptoms of this syndrome. Therefore, a better comprehension of LC and its modulators in breathing control is needed to clarify this issue.

\section{ACKNOWLEDGMENTS}

This research was supported by public funding from Fundação de Amparo à Pesquisa do Estado de São Paulo, the Conselho Nacional de Desenvolvimento Científico e Tecnológico (CNPq) and CAPES-PROEX.

\section{REFERENCES}

Abbracchio, M. P., and Burnstock, G. (1994). Purinoceptors: are there families of P2X and P2Y purinoceptors? Pharmacol. Ther. 64, 445-475. doi: 10.1016/01637258(94)00048-4

Abbracchio, M. P., Burnstock, G., Verkhratsky, A., and Zimmermann, H. (2009). Purinergic signalling in the nervous system: an overview. Trends Neurosci. 32, 19-29. doi: 10.1016/j.tins.2008.10.001

Aghajanian, G. K., and Vandermaelen, C. P. (1982). $\alpha 2$-Adrenoceptor-mediated hyperpolarization of locus coeruleus neurons: intracellular studies in vivo. Science 215, 1394-1396. doi: 10.1126/science.6278591

Aghajanian, G. K., and Wang, Y. Y. (1986). Pertussis toxin blocks the outward currents evoked by opiate and $\alpha$ 2-agonists in locus coeruleus neurons. Brain Res. 371, 390-394. doi: 10.1016/0006-8993(86)90382-3

Alvarez-Maubecin, V., Garcia-Hernandez, F., Williams, J. T., and Van Bockstaele, E. J. (2000). Functional coupling between neurons and glia. J. Neurosci. 20, 4091-4098.

Amir, R. E., Van den Veyver, I. B., Wan, M., Tran, C. Q., Francke, U., and Zoghbi, H. Y. (1999). Rett syndrome is caused by mutations in X-linked MECP2, encoding methyl-CpG-binding protein 2. Nat. Genet. 23, 185-188. doi: 10.1038/13810

Andrzejewski, M., Muckenhoff, K., Scheid, P., and Ballantyne, D. (2001). Synchronized rhythms in chemosensitive neurones of the locus coeruleus in the absence of chemical synaptic transmission. Respir. Physiol. 129, 123-140. doi: 10.1016/S0034-5687(01)00300-0

Anselmo-Franci, J. A., Peres-Polon, V. L., da Rocha-Barros, V. M., Moreira, E. R., Franci, C. R., and Rocha, M. J. (1998). C-fos expression and electrolytic lesions studies reveal activation of the posterior region of locus coeruleus during hemorrhage induced hypotension. Brain Res. 799, 278-284. doi: 10.1016/S00068993(98)00468-5

Antunes, V. R., Bonagamba, L. G., and Machado, B. H. (2005). Hemodynamic and respiratory responses to microinjection of ATP into the intermediate and caudal NTS of awake rats. Brain Res. 1032, 85-93. doi: 10.1016/j.brainres.2004. 10.048

Astier, B., Van Bockstaele, E. J., Aston-Jones, G., and Pieribone, V. A. (1990). Anatomical evidence for multiple pathways leading from the rostral ventrolateral medulla (nucleus paragigantocellularis) to the locus coeruleus in rat. Neurosci. Lett. 118, 141-146. doi: 10.1016/0304-3940(90)90612-D

Aston-Jones, G., Akaoka, H., Charléty, P., and Chouvet, G. (1991a). Serotonin selectively attenuates glutamate-evoked activation of noradrenergic locus coeruleus neurons. J. Neurosci. 11, 760-769.

Aston-Jones, G., Shipley, M. T., Chouvet, G., Ennis, M., Van Bockstaele, E., Pieribone, V., et al. (1991b). Afferent regulation of locus coeruleus neurons: anatomy, physiology and pharmacology. Prog. Brain Res. 88, 47-75. doi: 10.1016/S0079-6123(08)63799-1

Aston-Jones, G., Ennis, M., Pieribone, V. A., Nickell, W. T., and Shipley, M. T. (1986). The brain nucleus locus coeruleus: restricted afferent control of a broad efferent network. Science 234, 734-737. doi: 10.1126/science. 3775363

Aston-Jones, G., Foote, S. L., and Bloom, F. E. (1984). "Anatomy and physiology of locus coeruleus neurons: functional implications," in Norepinephrine (Frontiers of Clinical Neuroscience), Vol. 2, eds M. Ziegler and C. R. Lake (Baltimore: Williams and Wilkins), 92-116.

Aston-Jones, G., Shipley, M. T., and Grzanna, R. (1995). “The Locus coeruleus, A5 and A7 noradrenergic cell groups," in The Rat Nervous System, ed. G. Paxinos (Boca Raton: Academic Press), 183-213.

Ballantyne, D., Andrzejewski, M., Mückenhoff, K., and Scheid, P. (2004). Rhythms, synchrony and electrical coupling in the Locus coeruleus. Respir. Physiol. Neurobiol. 143, 199-214. doi: 10.1016/j.resp.2004. 07.018

Ballantyne, D., and Scheid, P. (2000). Mammalian brainstem chemosensitive neurones: linking them to respiration in vitro. J. Physiol. (Lond.) 525, 567-577. doi: 10.1111/j.1469-7793.2000.00567.x 
Baraban, J. M., and Aghajanian, G. K. (1981). Noradrenergic innervation of serotonergic neurons in the dorsal raphe: demonstration by eléctron microscopic autoradiography. Brain Res. 204, 1-11. doi: 10.1016/0006-8993(81) 90646-6

Baumgarten, H. G., and Göthert, M. (1997). "Serotoninergic neurons and 5-HT receptors in the CNS," in Handbook of Experimental Pharmacology, Vol. 129. Berlin: Springer.

Belliveau, D. J., Kidder, G. M., and Naus, C. C. G. (1991). Expression of gap junction genes during postnatal neural development. Dev. Genet. 12, 308-317. doi: 10.1002/dvg.1020120408

Belliveau, D. J., and Naus, C. C. G. (1995). Cellular localization of gap junction mRNAs in developing rat brain. Dev. Neurosci. 17, 81-96. doi: 10.1159/ 000111277

Belluardo, N., Mudo, G., Trovato-Salinaro, A., Le Gurun, S., Charollais, A., Serre-Beinier, V., etal. (2000). Expression of connexin36 in the adult and developing rat brain. Brain Res. 865, 121-138. doi: 10.1016/S0006-8993(00) 02300-3

Berridge, C. W., and Waterhouse, B. D. (2003). The Locus coeruleus-noradrenergic system: modulation of behavioral state and state-dependent cognitive processes. Brain Res. Brain Res. Rev. 42, 33-84. doi: 10.1016/S0165-0173(03) 00143-7

Beyer, E. C., Paul, D. L., and Goodenough, D. A. (1990). Connexin family of gap junction proteins. J. Membr. Biol. 116, 187-194. doi: 10.1007/BF01868459

Biancardi, V., Bícego, K. C., Almeida, M. C., and Gargaglioni, L. H. (2008). Locus coeruleus noradrenergic neurons and $\mathrm{CO}_{2}$ chemosensitivity. Pflugers Arch. 455, 1119-1128. doi: 10.1007/s00424-007-0338-8

Biancardi, V., Bícego, K. C., and Gargaglioni, L. H. (2014). ATP in the locus coeruleus as a modulator of cardiorespiratory control in unanaesthetized male rats. Exp. Physiol. 99, 232-247. doi: 10.1113/expphysiol.2013.074195

Bobker, D. H., and Williams, J. T. (1989). Serotonin agonists inhibit synaptic potentials in the rat locus ceruleus in vitro via 5-hydroxytryptaminelA and 5-hydroxytryptamine1B receptors. J. Pharmacol. Exp. Ther. 250, 37-43.

Boehm, S. (1999). ATP stimulates sympathetic transmitter release via presynaptic P2X purinoceptors. J. Neurosci. 19, 737-746.

Bonham, A. C. (1995). Neurotransmitters in the CNS control of breathing. Respir Physiol. 101, 219-230. doi: 10.1016/0034-5687(95)00045-F

Bowie, D. (2008). Ionotropic glutamate receptors and CNS disorders. CNS Neurol. Disord. Drug Targets 7, 129-143. doi: 10.2174/187152708784083821

Breen, L. A., Burde, R. M., and Loewy, A. D. (1983). Brainstem connections to the Edinger-Westphal nucleus of the cat: a retrograde tracer study. Brain Res. 261, 303-306. doi: 10.1016/0006-8993(83)90633-9

Brown, A. S., and Gershon, S. (1993). Dopamine and depression. J. Neural. Transm. 91, 75-109. doi: 10.1007/BF01245227

Bruzzone, R., and Ressot, C. (1997). Connexins, gap junctions and cell-cell signaling in the nervous system. Eur. J. Neurosci. 9, 1-6. doi: 10.1111/j.1460 9568.1997.tb01346.x

Bruzzone, R., White, T. W., and Paul, D. L. (1996). Connections with connexins: the molecular basis of direct intercellular signaling. Eur. J. Biochem. 238, 1-27. doi 10.1111/j.1432-1033.1996.0001q.x

Burnstock, G. (1972). Purinergic nerves. Pharmacol. Rev. 24, 509-581.

Burnstock, G. (1997). The past, present and future of purine nucleotides as signalling molecules. Neuropharmacology 36, 1127-1139. doi: 10.1016/S00283908(97)00125-1

Cedarbaum, J. M., and Aghajanian, G. K. (1978). Afferent projections to the rat locus coeruleus as determined by a retrograde tracing technique. J. Comp. Neurol. 178, 1-16. doi: 10.1002/cne.901780102

Champagnat, J., Denavit-Saubie, M., Moyanova, S., and Rondouin, G. (1982). Involvement of amino acids in periodic inhibitions of bulbar respiratory neurones. Brain Res. 237, 351-365. doi: 10.1016/0006-8993(82) 90447-4

Charney, D. S., and Redmond, D. E. (1983). Neurobiological mechanisms in human anxiety. Evidence supporting central noradrenergic hyperactivity. Neuropharmacology 22, 1531-1536. doi: 10.1016/0028-3908(83) 90122-3

Chiang, C., and Aston-Jones, G. (1993). A 5-hydroxytryptamine2 agonist augments $\gamma$-aminobutyric acid and excitatory amino acid inputs to noradrenergic locus coeruleus neurons. Neuroscience 54, 417-420. doi: 10.1016/03064522(93)90262-E
Christie, M. J., and Jelinek, H. F. (1993). Dye coupling among neurons of the rat Locus coeruleus during postnatal development. Neuroscience 56, 129-137. doi: 10.1016/0306-4522(93)90568-Z

Christie, M. J., Williams, J. T., and North, R. A. (1989). Electrical coupling synchronizes subthreshold activity in locus coeruleus neurons in vitro from neonatal rats. J. Neurosci. 9, 3584-3589.

Coates, E. L., Li, A., and Nattie, E. E. (1993). Widespread sites of brainstem ventilatory chemoreceptors. J. Appl. Physiol. 75, 5-14.

Condorelli, D. F., Parenti, R., Spinella, F., Trovato Salinaro, A., Belluardo, N., Cardile, V., et al. (1998). Cloning of a new gap junction gene (Cx36) highly expressed in mammalian brain neurons. Eur. J. Neurosci. 10, 1202-1208. doi: 10.1046/j.14609568.1998.00163.x

Dahl, G. (1996). Where are the gates in gap junction channels. Clin. Exp. Pharmacol. Physiol. 23, 1047-1052. doi: 10.1111/j.1440-1681.1996.tb01167.x

Davidson, J. S., and Baumgarten, I. M. (1988). Glycyrrhetinic acid derivatives: a novel class of inhibitors of gap junctional intercellular communication; structure activity relationship. J. Pharmacol. Exp. Ther. 246, 1104-1107.

Dean, J. B., Ballantyne, D., Cardone, D. L., Erlichman, J. S., and Solomon, I. C. (2002). Role of gap junctions in $\mathrm{CO}_{2}$ chemoreception and respiratory control. Am. J. Physiol. 283, 665-670.

Dean, J. B., Huang, R. Q., Erlichman, J. S., Southard, T. L., and Hellard, D. T. (1997). Cell-cell coupling occurs in dorsal medullary neurons after minimizing anatomicalcoupling artifacts. Neuroscience 80, 21-40. doi: 10.1016/S03064522(97)00016-X

Dean, J. B., Kinkade, E. A., and Putnam, R. W. (2001). Cell-cell coupling in $\mathrm{CO}_{2} / \mathrm{H}^{+}$-excited neurons in brainstem slices. Respir. Physiol. 129, 83-100. doi: 10.1016/S0034-5687(01)00284-5

de Carvalho, D., Bicego, K. C., de Castro, O. W., da Silva, G. S., Garcia-Cairasco, N., and Gargaglioni, L. H. (2010). Role of neurokinin-1 expressing neurons in the locus coeruleus on ventilatory and cardiovascular responses to hypercapnia. Respir. Physiol. Neurobiol. 172, 24-31. doi: 10.1016/j.resp.2010.04.016

Dermietzel, R., and Spray, D. C. (1993). Gap junctions in the brain: where, what type, how many and why? Trends Neurosci. 16, 186-192. doi: 10.1016/01662236(93)90151-B

Dermietzel, R., Traub, O., Hwang, T. K., Beyer, E., Bennet, V. L., and Spray, D. C. (1989). Differential expression of three gap junction proteins in developmental and mature brain tissues. Proc. Natl. Acad. Sci. U.S.A. 86, 10148-10152. doi: 10.1073/pnas.86.24.10148

de Souza Moreno, V., Bícego, K. C., Szawka, R. E., Anselmo-Franci, J. A., and Gargaglioni, L. H. (2010). Serotonergic mechanisms on breathing modulation in the rat locus coeruleus. Pflügers Arch. 459, 357-368. doi: 10.1007/s00424-0090741-4

Dillon, G. H., Welsh, D. E., and Waldrop, T. G. (1991). Modulation of respiratory reflexes by an excitatory amino acid mechanism in the ventrolateral medulla. Respir. Physiol. 85, 55-72. doi: 10.1016/0034-5687(91)90006-5

Edwards, F. A., and Gibb, A. J. (1993). ATP - a fast neurotransmitter. FEBS Lett. 325, 86-89. doi: 10.1016/0014-5793(93)81419-Z

Ennis, M., and Aston-Jones, G. (1987). Two physiologically distinct populations of neurons in the ventrolateral medulla innervate the locus coeruleus. Brain Res. 425, 275-282. doi: 10.1016/0006-8993(87)90510-5

Ennis, M., Aston-Jones, G., and Shiekhattar, R. (1992). Activation of locus coeruleus neurons by nucleus paragigan to cellularis or noxious sensory stimulation is mediated by intracoerulear excitatory amino acid neurotransmission. Brain Res. 598, 185-195. doi: 10.1016/0006-8993(92)90182-9

Fabris, G., Anselmo-Franci, J. A., and Branco, L. G. (1999). Role of nitric oxide in hypoxia-induced hyperventilation and hypothermia: participation of the locus coeruleus. Braz. J. Med. Biol. Res. 32, 1389-1398. doi: 10.1590/S0100879X1999001100009

Ferreira, C. M., de Paula, P. M., and Branco, L. G. (2004). Role of L-glutamate in the locus coeruleus of rats in hypoxia-induced hyperventilation and anapyrexia. Respir. Physiol. Neurobiol. 139, 157-166. doi: 10.1016/j.resp.2003. 10.001

Filosa, J. A., Dean, J. B., and Putnam, R. W. (2002). Role of intracellular and extracellular $\mathrm{pH}$ in the chemosensitive response of rat Locus coeruleus neurones. J. Physiol. 541(Pt 2), 493-509. doi: 10.1113/jphysiol.2001. 014142

Fitzgerald, P. J. (2012). The NMDA receptor may participate in widespread suppression of circuit level neural activity, in addition to a similarly prominent 
role in circuit level activation. Behav. Brain Res. 230, 291-298. doi: 10.1016/j.bbr.2012.01.057

Foote, S. L., Bloom, F. E., and Aston-Jones, G. (1983). Nucleus locus ceruleus: new evidence of anatomical and physiological specificity. Physiol. Rev. 63, 844-914.

Fredholm, B. B., Abbracchio, M. P., Burnstock, G., Daly, J. W., Harden, T. K., Jacobson, K. A., et al. (1994). Nomenclature and classification of purinoceptors. Pharmacol. Rev. 46, 143-156.

Frisch, C., De Souza-Silva, M. A., Söhl, G., Güldenagel, M., Willecke, K., Huston, J. P., et al. (2005). Stimulus complexity dependent memory impairment and changes in motor performance after deletion of the neuronal gap junction protein connexin36 in mice. Behav. Brain Res. 157, 177-185. doi: 10.1016/j.bbr.2004.06.023

Fukui, M., Takishita, A., Zhang, N., Nakagawa, T., Minami, M., and Satoh, M. (2004). Involvement of locus coeruleus noradrenergic neurons in supraspinal antinociceptin by $\alpha, \beta$-methylene-ATP in rats. J. Pharmacol. Sci. 94, 153-160. doi: 10.1254/jphs.94.153

Gargaglioni, L. H., Hartzler, L. K., and Putnam, R. W. (2010). The Locus coeruleus and central chemosensitivity. Respir. Physiol. Neurobiol. 173, 264-273. doi 10.1016/j.resp.2010.04.024

González, A., and Smeets, W. J. (1993). Noradrenaline in the brain of the South African clawed frog Xenopus laevis: a study with antibodies against noradrenaline and dopamine- $\beta$-hydroxylase. J. Comp. Neurol. 331, 363-374. doi: $10.1002 / \mathrm{cne} .903310306$

Gonzalez, M. M., and Aston-Jones, G. (2006). Circadian regulation of arousal: role of the noradrenergic locus coeruleus system and light exposure. Sleep 29 1327-1336.

Goodenough, D. A., Goliger, J. A., and Paul, D. L. (1996). Connexins, connexons, and intercellular communication. Annu. Rev. Biochem. 65, 475-502. doi: 10.1146/annurev.bi.65.070196.002355

Gourine, A. V., Melenchuk, E. V., Poputnikov, D. M., Gourine, V. N., and Spyer, K. M. (2002). Involvement of purinergic signalling in central mechanisms of body temperature regulation in rats. Br. J. Pharmacol. 135, 2047-2055. doi: 10.1038/sj.bjp.0704679

Gourine, A. V., Atkinson, L., Deuchars, J., and Spyer, K. M. (2003). Purinergic signalling in the medullary mechanisms of respiratory control in the rat: respiratory neurones express the P2X2 receptor subunit. J. Physiol. 552(Pt 1), 197-211. doi: 10.1113/jphysiol.2003.045294

Gourine, A. V., Llaudet, E., Dale, N., and Spyer, K. M. (2005). ATP is a mediator of chemosensory transduction in the central nervous system. Nature 436, 108-111. doi: $10.1038 /$ nature 03690

Haddjeri, N., Montigny, C., and Blier, P. (1997). Modulation of the firing activity of noradrenergic neurones in the rat locus coeruleus by the 5hydroxtryptamine system. Br. J. Pharmacol. 120, 865-875. doi: 10.1038/sj.bjp. 0700968

Harms, L., Finta, E. P., Tschöpl, L. M., and Illes, P. (1992). Depolarization of rat locus coeruleus neurons by adenosine 5' -triphosphate. Neuroscience 48, 941-952. doi: 10.1016/0306-4522(92)90282-7

Hartfield, E. M., Rinaldi, F., Glover, C. P., Wong, L. F., Caldwell, M. A., and Uney, J. B. (2011). Connexin 36 expression regulates neuronal differentiation from neural progenitor cells. PLoS ONE 6:e14746. doi: 10.1371/journal.pone. 0014746

Hartzler, L. K., Dean, J. B., and Putnam, R. W. (2007). Developmental changes in the chemosensitive response in locus coeruleus neurons from neonatal rats. Soc. Neurosci. Abstr. 33, 297-298.

Hayashida, K., Parker, R. A., and Eisenach, J. C. (2010). Activation of glutamate transporters in the locus coeruleus paradoxically activates descending inhibition in rats. Brain Res. 1317, 80-86. doi: 10.1016/j.brainres.2009. 12.086

Henny, P., Brischoux, F., Mainville, L., Stroh, T., and Jones, B. E. (2010). Immunohistochemical evidence for synaptic release of glutamate from orexin terminals in the locus coeruleus. Neuroscience 169, 1150-1157. doi: 10.1016/j.neuroscience.2010.06.003

Hermann, D. M., Luppi, P. H., Peyron, C., Hinckel, P., and Jouvet, M. (1997). Afferent projections to the rat nuclei raphe magnus, raphe pallidus and reticularis gigantocellularis pars $\alpha$ demonstrated by iontophoretic application of choleratoxin (subunit b). J. Chem. Neuroanat. 13, 1-21. doi: 10.1016/S0891-0618(97) 00019-7
Hewitt, A., Barrie, R., Graham, M., Bogus, K., Leiter, J. C., and Erlichman, J. S. (2004). Ventilatory effects of gap junction blockade in the RTN in awake rats. Am. J. Physiol. Regul. Integr. Comp. Physiol. 287, 1407-1418. doi: 10.1152/ajpregu.00404.2004

Hilaire, G., Viemari, J. C., Coulon, P., Simonneau, M., and Bévengut, M. (2004) Modulation of the respiratory rhythm generator by the pontine noradrenergic A5 and A6 groups in rodents. Respir. Physiol. Neurobiol. 143, 187-197. doi: 10.1016/j.resp.2004.04.016

Holloway, B. B., Stornetta, R. L., Bochorishvili, G., Erisir, A., Viar, K. E., and Guyenet, P. (2013). Monosynaptic glutamatergic activation of locus coeruleus and other lower brainstem noradrenergic neurons by the $\mathrm{Cl}$ cells in mice. J. Neurosci. 33, 18792-18805. doi: 10.1523/JNEUROSCI.2916-13.2013

Homayoun, H., and Moghaddam, B. (2007). NMDA receptor hypofunction produces opposite effects on prefrontal cortex interneurons and pyramidal neurons. J. Neurosci. 27, 11496-11500. doi: 10.1523/JNEUROSCI.221307.2007

Hooper, M. L., and Subak-Sharpe, J. H. (1981). Metabolic co-operation between cells. Int. Rev. Cytol. 69, 45-104.

Horvath, T. L., Diano, S., and Van den Pol, A. N. (1999). Synaptic interaction between hypocretin (orexin) and neuropeptide $\mathrm{Y}$ cells in the rodent and primate hypothalamus: a novel circuit implicated in metabolic and endocrine regulations. J. Neurosci. 19, 1072-1087.

Huxtable, A. G., Zwicker, J. D., Poon, B. Y., Pagliardini, S., Vrouwe, S. Q., Greer, J. J., et al. (2009). Tripartite purinergic modulation of central respiratory networks during perinatal development: the influence of ATP, ectonucleotidases, and ATP metabolites. J. Neurosci. 29, 14713-14725. doi: 10.1523/JNEUROSCI.266009.2009

Iijima, K., and Ohtomo, K. (1988). Immunocytochemical study using a GABA antiserum for the demonstration of inhibitory neurons in the rat locus ceruleus. Am. J. Anat. 181, 43-52. doi: 10.1002/aja.1001810106

Illes, P., Sevcik, J., Finta, E. P., Frohlich, R., Nieber, K., and Norenberg, W. (1994) Modulation of locus coeruleus neurons by extra- and intracellular adenosine 50triphosphate. Brain Res. Bull. 35, 513-519. doi: 10.1016/0361-9230(94)90165-1

Ishimatsu, M., and Williams, J. T. (1996). Synchronous activity in locus coeruleus results from dendritic interactions in pericoerulear regions. J. Neurosci. 16, 51965204.

Jacobs, B. L., and Azmitia, E. C. (1992). Structure and function of the brain serotonin system. Physiol. Rev. 72, 165-229.

Jones, B. E. (2005). "Basic mechanisms of sleep-wake states," in Principles and Practice of Sleep Medicine, eds M. H. Kryger, T. Roth, and W. C. Dement (Philadelphia: Elsevier Saunders), 136-153. doi: 10.1016/B0-72-160797-7/50018-5

Jones, B. E., and Yang, T. Z. (1985). The efferent projections from the reticular formation and the locus coeruleus studied by anterograde and retrograde axonal transport in the rat. J. Comp. Neurol. 242, 56-92. doi: 10.1002/cne.902420105

Jouvet, M. (1999). Sleep and serotonin: an unfinished story. Neuropsychopharmacology 21(Suppl. 1), 24S-27S. doi: 10.1016/S0893-133X(99)00009-3

Kaehler, S. T., Singewald, N., and Philippu, A. (1999). Dependence of serotonin release in the locus coeruleus on dorsal raphe neuronal activity. Naunyn Schmiedebergs Arch. Pharmacol. 359, 386-393. doi: 10.1007/ PL00005365

Kanjhan, R., Housley, G. D., Burton, L. D., Christie, D. L., Kippenberger, A., Thorne, P. R., et al. (1999). Distribution of the P2X2 receptor subunit of the ATP-gated ion channels in the rat central nervous system. J. Comp. Neurol. 407, 11-32. doi: 10.1002/(SICI)1096-9861(19990428)407:1<11::AID-CNE2>3.0. CO;2-R

Khakpay, R., Polster, D., Köles, L., Skorinkin, A., Szabo, B., Wirkner, K., et al. (2010). Potentiation of the glutamatergic synaptic input to rat locus coeruleus neurons by P2X7 receptors. Purinergic Signal. 6, 349-359. doi: 10.1007/s11302-0109198-3

Kim, M. A., Lee, H. S., Lee, B. Y., and Waterhouse, B. D. (2004). Reciprocal connections between subdivisions of the dorsal raphe and the nuclear core of the locus coeruleus in the rat. Brain Res. 1026, 56-67. doi: 10.1016/j.brainres.2004. 08.022

Kumar, N. M., and Gilula, N. B. (1996). The gap junction communication channel. Cell 84, 381-388. doi: 10.1016/S0092-8674(00)81282-9

Kuwahata, T. (2004). Effects of adenosine and ATP on the membrane potential and synaptic transmission in neurons of the rat locus coeruleus. Kurume Med. J. 51, 109-123. doi: 10.2739/kurumemedj.51.109 
Laird, D. W. (2006). Life cycle of connexins in health and disease. Biochem. J. 394, 527-543. doi: 10.1042/BJ20051922

Li, Z. Y., Xia, B. L., and Huang, C. J. (1992). Effects of microinjection of L-glutamate into locus coeruleus complex area on respiration. J. Tongji Med. Univ. 12, 205-208. doi: $10.1007 / \mathrm{BF} 02887850$

Liu, G., Feldman, J. L., and Smith, J. C. (1990). Excitatory amino acid-mediated transmission of inspiratory drive to phrenic motoneurons. J. Neurophysiol. 64, 423-436.

Llewellyn-Smith, I. J., and Burnstock, G. (1998). Ultrastructural localization of P2X3 receptors in rat sensory neurons. Neuroreport 9, 2545-2550. doi: 10.1097/00001756-199808030-00022

Loewenstein, W. R. (1981). Junctional intercellular communication: the cell-to-cell membrane channel. Physiol. Rev. 61, 829-913.

Lorier, A. R., Huxtable, A. G., Robinson, D. M., Lipski, J., Housley, G. D., and Funk, G. D. (2007). P2Y1 receptor modulation of the pre-Bötzinger complex inspiratory rhythm generating network in vitro. J. Neurosci. 27, 993-1005. doi: 10.1523/JNEUROSCI.3948-06.2007

Lorier, A. R., Lipski, J., Housley, G. D., Greer, J. J., and Funk, G. D. (2008). ATP sensitivity of preBötzinger complex neurones in neonatal rat in vitro: mechanism underlying a P2 receptor-mediated increase in inspiratory frequency. J. Physiol. 586, 1429-1446. doi: 10.1113/jphysiol.2007.143024

Luppi, P. H., Aston-Jones, G., Akaoka, H., Chouvet, G., and Jouvet, M. (1995). Afferent projections to the rat locus coeruleus demonstrated by retrograde and anterograde tracing with cholera-toxin B subunit and PHA-L. Neuroscience 65, 119-160. doi: 10.1016/0306-4522(94)00481-J

Mateo, J., García-Lecea, M., Miras-Portugal, M. T., and Castro, E. (1998). Ca ${ }^{2+}$ signals mediated by P2X-type purinoceptors in cultured cerebellar Purkinje cells J. Neurosci. 18, 1704-1712.

Meltzer, H. Y., and Lowy, M. T. (1987). "The serotonin hypothesis of depression," in Psychopharmacology: The Third Generation of Progress, ed. H. Y. Meltzer (New York, NY: Raven Press), 513-525.

Miyawaki, T., Kawamura, H., Komatsu, K., and Yasugi, T. (1991). Chemical stimulation of the locus coeruleus: inhibitory effects on hemodynamics and renal sympathetic nerve activity. Brain Res. 568, 101-108. doi: 10.1016/00068993(91)91384-D

Mokha, S. S., McMillan, J. A., and Iggo, A. (1985). Descending control of spinal nociceptive transmission. Actions produced on spinal multireceptive neurones from the nuclei locus coeruleus (LC) and raphe magnus (NRM). Exp. Brain. Res. 58, 213-226. doi: 10.1007/BF00235305

Morgane, P. J., and Jacobs, M. S. (1979). Raphe projections to the locus coeruleus in the rat. Brain Res. Bull. 4, 519-534. doi: 10.1016/0361-9230(79) 90037-6

Nadarajah, B., Jones, A. M., Evans, W. H., and Parnavelas, J. G. (1997). Differential expression of connexins during neocortical development and neuronal circuit formation. J. Neurosci. 17, 3096-3111.

Nattie, E. (1999). $\mathrm{CO}_{2}$, brainstem chemoreceptors and breathing. Prog. Neurobiol 59, 299-331. doi: 10.1016/S0301-0082(99)00008-8

Naus, C. C. G., and Bani-Yaghoub, M. (1998). Gap junctional communication in the developing central nervous system. Cell Biol. Int. 22, 751-763. doi: 10.1006/cbir.1998.0391

Nestler, E. J., Alreja, M., and Aghajanian, G. K. (1999). Molecular control of locus coeruleus neurotransmission. Biol. Psychiatry 46, 1131-1139. doi: 10.1016/S0006-3223(99)00158-4

Nichols, N. L., Hartzler, L. K., Conrad, S. C., Dean, J. B., and Putnam, R.W. (2008). Intrinsic chemosensitivity of individual nucleus tractus solitarius (NTS) and locus coeruleus (LC) neurons from neonatal rats. Adv. Exp. Biol. Med. 605, 348-352. doi: 10.1007/978-0-387-73693-8_61

Nieber, K., Poelchen, W., and Illes, P. (1997). Role of ATP in fast excitatory synaptic potentials in locus coeruleus neurones of the rat. Br. J. Pharmacol. 122, 423-430. doi: 10.1038/sj.bjp.0701386

Noronha-de-Souza, C. R., Bícego, K. C., Michel, G., Glass, M. L., Branco, L. G. S., and Gargaglioni, L. H. (2006). Locus coeruleus is a central chemoreceptive site in toads. Am. J. Physiol. Regul. Integr. Comp. Physiol. 291, 997-1006. doi: 10.1152/ajpregu.00090.2006

Nygren, L. G., and Olson, L. (1977). A new major projection from locus coeruleus: the main source of noradrenergic nerve terminals in the ventral and dorsal columns of the spinal cord. Brain Res. 132, 85-93. doi: 10.1016/0006-8993(77)90707-7
Olpe, H. R., and Steinmann, M. (1991). Responses of locus coeruleus neurons to neuropeptides. Prog. Brain Res. 88, 241-248. doi: 10.1016/S0079-6123(08) 63813-3

Oyamada, Y., Andrzejewski, M., Mückenhoff, K., Scheid, P., and Ballantyne, D. (1999). Locus coeruleus neurones in vitro: $\mathrm{pH}$-sensitive oscillations of membrane potential in an electrically coupled network. Respir. Physiol. 118(2-3), 131-147. doi: 10.1016/S0034-5687(99)00088-2

Oyamada, Y., Ballantyne, D., Muckenhoff, K., and Scheid, P. (1998). Respirationmodulated membrane potential and chemosensitivity of locus coeruleus neurones in the in vitro brainstem-spinal cord of the neonatal rat. J. Physiol. 513(Pt 2), 381-398. doi: 10.1111/j.1469-7793.1998.381bb.x

Parisian, K., Wages, P., Smith, A., Jarosz, J., Hewitt, A., Leiter, J. C., et al. (2004). Ventilatory effects of gap junction blockade in the NTS in awake rats. Respir. Physiol. Neurobiol. 142, 127-143. doi: 10.1016/j.resp.2004.06.014

Pasquier, D. A., Kemper, T. L., Forbes, W. B., and Morgane, P. J. (1977). Dorsal raphe, substantia nigra and locus coeruleus: interconnections with each other and the neostriatum. Brain Res. Bull. 2, 323-339. doi: 10.1016/0361-9230(77) 90066-1

Patrone, L. G. A., Bícego, K. C., Hartzler, L. K., Putnam, R. W., and Gargaglioni, L. H. (2014). Cardiorespiratory effects of gap junction blockade in the locus coeruleus in unanesthetized adult rats. Respir. Physiol. Neurobiol. 190, 86-95. doi: 10.1016/j.resp.2013.09.001

Petralia, R. S., Yokotani, N., and Wenthold, R. J. (1994). Light and electron microscope distribution of the NMDA receptor subunit NMDAR1 in the rat nervous system using a selective anti-peptide antibody. J. Neurosci. 14, 667-696.

Peyron, C., Luppi, P. H., Fort, P., Rampon, C., and Jouvet, M. (1996). Lower brainstem catecholamine afferents to the rat dorsal raphe nucleus. J. Comp. Neurol. 364, 402-413. doi: 10.1002/(SICI)1096-9861(19960115)364:3<402::AIDCNE2>3.0.CO;2-8

Peyron, C., Tighe, D. K., van den Pol, A. N., de Lecea, L., Heller, H. C., Sutcliffe, J. G. et al. (1998). Neurons containing hypocretin (orexin) project to multiple neuronal systems. J. Neurosci. 18, 9996-10015.

Pickel, V., Joh, T. H., and Reis, D. J. (1977) A serotoninergic innervation of noradrenergic neurons in nucleus locus coeruleus: demonstration by immunocytochemical localization of the transmitter specific enzyme tyrosine and tryptophan hydroxylase. Brain Res. 131, 197-214. doi: 10.1016/0006-8993(77) 90515-7

Picoli, C., Nouvel, V., Aubry, F., Reboul, M., Duchêne, A., Jeanson, T., et al. (2012). Human connexin channel specificity of classical and new gap junction inhibitors. J. Biomol. Screen. 17, 1339-1347. doi: 10.1177/1087057112452594

Pierce, M. L., Deuchars, J., and Deuchars, S. A. (2010). Spontaneous rhythmogenic capabilities of sympathetic neuronal assemblies in the rat spinal cord slice. Neuroscience 170, 827-838. doi: 10.1016/j.neuroscience.2010. 07.007

Pieribone, V. A., and Aston-Jones, G. (1991). Adrenergic innervation of the rat nucleus locus coeruleus arises predominantly from the $\mathrm{C} 1$ adrenergic cell group in the rostral medulla. Neuroscience 41, 525-542. doi: 10.1016/03064522(91)90346-P

Pineda, J., and Aghajanian, G. K. (1997). Carbon dioxide regulates the tonic activity of locus ceruleus neurons by modulating a proton- and polyaminesensitive inward rectifier potassium current. Neuroscience 77, 723-743. doi: 10.1016/S0306-4522(96)00485-X

Poelchen, W., Sieler, D., Wirkner, K., and Illes, P. (2001). Co-transmitter function of ATP in central catecholaminergic neurons of the rat. Neuroscience 102, 593-602. doi: 10.1016/S0306-4522(00)00529-7

Pollard, H., Llorens-Cortes, C., Barbin, G., Garbarg, M., and Schwartz, J. C. (1978). Histamine and histidine decarboxylase in brain stem nuclei: distribution and decrease after lesions. Brain Res. 157, 178-181. doi: 10.1016/00068993(78)91010-7

Putnam, R. W. (2001). Intracellular pH regulation of neurons in chemosensitive and nonchemosensitive areas of brain slices. Respir. Physiol. 129, 37-56. doi: 10.1016/S0034-5687(01)00281-X

Putnam, R. W., Filosa, J. A., and Ritucci, N. A. (2004) Cellular mechanisms involved in $\mathrm{CO}_{2}$ and acid signaling in chemosensitive neurons. Am. J. Physiol. Cell. Physiol. 287, 1493-1526. doi: 10.1152/ajpcell.00282.2004

Rash, J. E., Olson, C. O., Davidson, K. G., Yasumura, T., Kamasawa, N., and Nagy, J. I. (2007). Identification of connexin 36 in gap junctions 
between neurons in rodent locus coeruleus. Neuroscience 147, 938-956. doi: 10.1016/j.neuroscience.2007.04.061

Redmond, D. J., and Huang, Y. H. (1979). Current concepts. II. New evidencefor a locus coeruleus-norepinephrine connection with anxiety. Life Sci. 25, 2149-2162. doi: 10.1016/0024-3205(79)90087-0

Reil, J. C. (1809). Untersuchungen uber den Bau des grossen Gehims im Menschen. Arch. Physiol. 9, 136-524.

Rekling, J. C., and Feldman, J. L. (1997). Bidirectional electrical coupling between inspiratory motoneurons in the newborn mouse nucleus ambiguus. $J$. Neurophysiol. 78, 3508-3510.

Ruggiero, R. N., Bueno-Juúnior, L. S., Ross, J. B., Fachim, H. A., PadovanNeto, F. E., Merlo, S., et al. (2011). Neurotransmissão glutamateérgica e a plasticidade sinaáptica: aspectos moleculares, clínicos e filogenéticos. Medicina (Ribeirão Preto) 44, 143-156. doi: 10.11606/issn.2176-7262. v44i2p143-156

Russell, G. V. (1955). The nucleus locus coeruleus (dorsolateralis tegmenti). Tex. Rep. Biol. Med. 13, 939-988.

Samuels, E.R., and Szabadi, E. (2008). Functional neuroanatomy of the noradrenergic locus coeruleus: its roles in the regulation of arousal and autonomic function part Il: Physiological and Pharmacological Manipulations and Pathological Alterations of Locus Coeruleus Activity in Humans. Curr. Neuropharmacol. 6(3), 254-285. doi: 10.2174/157015908785777193

Santin, J. M., and Hartzler, L. K. (2013). Respiratory signaling of locus coeruleus neurons during hypercapnic acidosis in the bullfrog, Lithobates cates beianus. Respir. Physiol. Neurobiol. 185, 553-561. doi: 10.1016/j.resp.2012. 11.002

Saper, C. B., Chou, T. C., and Scammell, T. E. (2001). The sleep switch: hypothalamic control of sleep and wakefulness. Trends Neurosci. 24, 726-731. doi 10.1016/S0166-2236(00)02002-6

Sato, K., Kiyama, H., and Tohyama, M. (1993). The differential expression patterns of messenger RNAs encoding non- $N$-methyl-D-aspartate glutamate receptor subunits (GluR1-4) in the rat brain. Neuroscience 52, 515-539. doi 10.1016/0306-4522(93)90403-3

Scheibler, P., Pesic, M., Franke, H., Reinhardt, R., Wirkner, K., Illes, P., et al (2004). P2X2 and P2Y1 immunofluorescence in rat neostriatal medium-spiny projection neurones and cholinergic interneurones is not linked to respective purinergic receptor function. Br. J. Pharmacol. 143, 119-131. doi: 10.1038/sj.bjp. 0705916

Schreihofer, A. M., Stornetta, R. L., and Guyenet, P. G. (1999). Evidence for glycinergic respiratory neurons: Botzinger neurons express mRNA for glycinergic transporter 2. J. Comp. Neurol. 407, 583-597. doi: 10.1002/(SICI)10969861(19990517)407:4<583::AID-CNE8>3.0.CO;2-E

Segal, M. (1979). Serotonergic innervation of the locus coeruleus from the dorsal raphe and its action on responses to noxious stimuli. J. Physiol. 286, 401-415.

Seiver, L. J. (1987). "Role of noradrenergic mechanisms in the etiology of the affective disorders," in Psychopharmacology: The Third Generation of Progress, ed. H. Y. Meltzer (New York, NY: Raven Press), 493-504.

Shen, K. Z., and North, R. A. (1993). Excitation of rat locus coeruleus neurons by adenosine $5^{\prime}$-triphosphate: ionic mechanism and receptor characterization. J. Neurosci. 13, 894-899.

Singewald, N., and Philippu, A. (1998). Release of neurotransmitters in the locus coeruleus. Prog. Neurobiol. 56, 237-267. doi: 10.1016/S0301-0082(98) 00039-2

Sohl, G., Degen, J., Teubner, B., and Willecke, K. (1998). The murine gap junction gene connexin 36 is highly expressed in mouse retina and regulated during brain development. FEBS Lett. 428, 27-31. doi: 10.1016/S0014-5793(98) 00479-7

Solomon, I. C. (2003). Connexin 36 distribution in putative $\mathrm{CO}_{2}$-chemosensitive brainstem regions in rat. Respir. Physiol. Neurobiol. 139, 1-20. doi: 10.1016/j.resp.2003.09.004

Solomon, I. C., and Dean, J. B. (2002). Gap junctions in $\mathrm{CO}_{2}$-chemoreception and respiratory control. Respir. Physiol. Neurobiol. 131, 155-173. doi: 10.1016/S15699048(02)00090-3

Solomon, I. C., Edelman, N. H., and Neubauer, J. A. (2000). Pre-Bötzinger complex functions as a central hypoxia chemosensor for respiration in vivo. J. Neurophysiol. $83,2854-2868$

Solomon, I. C., Halat, T. J., El-Maghrabi, M. R., and O’Neal, M. H. (2001). Localization of connexin 26 and connexin 32 in putative $\mathrm{CO}_{2}$-chemosensitivie brainstem regions in rat. Respir. Physiol. 129, 101-121. doi: 10.1016/S0034-5687(01) 00299-7

Spyer, K. M., Dale, N., and Gourine, A. V. (2004). ATP is a key mediator of central and peripheral chemosensory transduction. Exp. Physiol. 98, 53-59. doi: 10.1113/expphysiol.2003.002659

Sutin, E. L., and Jacobowitz, D. M. (1991). Neurochemicals in the dorsal pontine tegmentum. Prog. Brain Res. 88, 3-14. doi: 10.1016/S0079-6123(08) 63796-6

Sved, A. F., and Felsten, G. (1987). Stimulation of the locus coeruleus decreases arterial pressure. Brain Res. 414, 119-132. doi: 10.1016/0006-8993(87) 91332-1

Swanson, L. W., and Hartman, B. K. (1975). The central adrenergic system. An immunofluorescence study of the location of cell bodies and their efferent connections in the rat utilizing dopamine- $\beta$-hydroxylase as a marker. J. Comp. Neurol. 163, 467-505. doi: 10.1002/cne. 901630406

Swanson, L. W., and Sawchenko, P. E. (1983). Hypothalamic integration: organization of the paraventricular and supraoptic nuclei. Annu. Rev. Neurosci. 6, 269-324. doi: 10.1146/annurev.ne.06.030183.001413

Szabo, S. T., and Blier, P. (2001). Functional and pharmacological characterization of the modulatory role of serotonin on the firing activity of locus coeruleus norepinephrine neurons. Brain Res. 922, 9-20. doi: 10.1016/S0006-8993(01) 03121-3

Taneja, P., Ogier, M., Brooks-Harris, G., Schmid, D. A., Katz, D. M., and Nelson, S. B. (2009). Pathophysiology of locus ceruleus neurons in a mouse model of Rett syndrome. J. Neurosci. 29, 12187-12195. doi: 10.1523/JNEUROSCI.315609.2009

Taxini, C. L., Puga, C. C. I., Dias, M. B., Bícego, K. C., and Gargaglioni, L. H. (2013). Ionotropic but not metabotropic glutamatergic receptors in the locus coeruleus modulate the hypercapnic ventilatory response in unanaesthetized rats. Acta Physiol. 208, 125-135. doi: 10.1111/apha.12082

Thomas, T., Ralevic, V., Bardini, M., Burnstock, G., and Spyer, K. M. (2001). Evidence for the involvement of purinergic signalling in the control of respiration. Neuroscience 107, 481-490. doi: 10.1016/S0306-4522(01) 00363-3

Thomas, T., and Spyer, K. M. (2000). ATP as a mediator of mammalian central $\mathrm{CO}_{2}$ chemoreception. J. Physiol. 523(Pt 2), 441-447. doi: 10.1111/j.14697793.2000.00441.x

Törk, I. (1990). Anatomy of the serotonergic system. Ann. N. Y. Acad. Sci. 600, 9-34; discussion 34-35. doi: 10.1111/j.1749-6632.1990.tb16870.x

Travagli, R. A., Dunwiddie, T. V., and Williams, J. T. (1995). Opioid inhibition in locus coeruleus. J. Neurophysiol. 74, 518-528.

Tschöpl, M., Harms, L., Norenberg, W., and Illes, P. (1992). Excitatory effects of adenosine $5^{\prime}$-triphosphate on rat locus coeruleus neurones. Eur. J. Pharmacol. 213, 71-77. doi: 10.1016/0014-2999(92)90234-U

Uhde, T. W., Boulenger, J. P., Post, R. M., Siever, L. J., Vittone, B. J., Jimerson, D. C., et al. (1984). Fear and anxiety: relationship to noradrenergic function. Psychopathology 17(Suppl. 3), 8-23. doi: 10.1159/000284127

Van Bockstaele, E. J., Pieribone, V. A., and Aston-Jones, G. (1989) Diverse afferents converge on the nucleus paragigantocellularis in the rat ventrolateral medulla: retrograde and anterograde tracing studies. J. Comp. Neurol. 290, 561-584. doi: $10.1002 / \mathrm{cne} .902900410$

Vertes, R., and Kocsis, B. (1994) Projections of the dorsal raphe nucleus to the brainstem: PHA-L analysis in the rat. J. Comp. Neurol. 340, 11-26. doi: 10.1002/cne.903400103

Viemari, J. C., Bévengut, M., Burnet, H., Coulon, P., Pequignot, J. M., Tiveron, M. C., et al. (2004). Phox2a gene, A6 neurons, and noradrenaline are essential for development of normal respiratory rhythm in mice. J. Neurosci. 24, 928-937. doi: 10.1523/JNEUROSCI.3065-03.2004

Virginio, C., MacKenzie, A., Rassendren, F. A., North, R. A., and Surprenant, A. (1999). Pore dilation of neuronal P2X receptor channels. Nat. Neurosci. 2, 315321. doi: 10.1038/7225

von Kügelgen, I., Späth, L., and Starke, K. (1994). Evidence for P2-purinoceptormediated inhibition of noradrenaline release in the rat brain cortex. Br. J. Pharmacol. 113, 815-822. doi: 10.1111/j.1476-5381.1994.tb17066.x

von Kügelgen, I., Stöffel, D., and Starke, K. (1995). P2-purinoceptor-mediated inhibition of noradrenaline release in rat atria. Br. J. Pharmacol. 115, 247-254. doi: 10.1111/j.1476-5381.1995.tb15870.x 
Vulchanova, L., Riedl, M. S., Shuster, S. J., Buell, G., Surprenant, A., North, R. A., etal. (1997). Immunohistochemical study of the P2X2 and P2X3 receptor subunits in rat and monkey sensory neurons and their central terminals. Neuropharmacology 36, 1229-1242. doi: 10.1016/S0028-3908(97) 00126-3

Westlund, K. N., Bowker, R. M., Ziegler, M. G., and Coulter, J. D. (1983) Noradrenergic projections to the spinal cord of the rat. Brain Res. 263, 15-31. doi: 10.1016/0006-8993(83)91196-4

Williams, J. T., Henderson, G., and North, R. A. (1985). Characterization of $\alpha$ 2-adrenoceptors which increase potassium conductance in rat locus coeruleus neurones. Neuroscience 14, 95-101. doi: 10.1016/0306-4522(85) 90166-6

Williams, J. T., and Marshall, K. C. (1987). Membrane properties and adrenergic responses in locus coeruleus neurones of young rats. J. Neurosci. 7, 3687-3694.

Wisden, W., and Seeburg, P. H. (1993). A complex mosaic of high-affinity kainate receptors in rat brain. J. Neurosci. 13, 3582-3598.

Yao, S. T., Barden, J. A., Finkelstein, D. I., Bennett, M. R., and Lawrence, A. J. (2000). Comparative study on the distribution patterns of P2X1-P2X6 receptor immunoreactivity in the brainstem of the rat and the common marmoset ( Callithrix jacchus): association with catecholamine cell groups. J. Comp. Neurol. 427, 485-507. doi: 10.1002/1096-9861(20001127)427:4<485::AID-CNE1>3. $0 . \mathrm{CO} ; 2-\mathrm{S}$
Yao, S. T., and Lawrence, A. J. (2005). Purinergic modulation of cardiovascular function in the rat locus coeruleus. Br. J. Pharmacol. 145, 342-352. doi 10.1038/sj.bjp.0706179

Conflict of Interest Statement: The authors declare that the research was conducted in the absence of any commercial or financial relationships that could be construed as a potential conflict of interest.

Received: 28 April 2014; paper pending published: 22 May 2014; accepted: 14 July 2014; published online: 05 August 2014.

Citation: de Carvalho D, Patrone LGA, Taxini CL, Biancardi V, Vicente MC and Gargaglioni LH (2014) Neurochemical and electrical modulation of the locus coeruleus: contribution to $\mathrm{CO}_{2}$ drive to breathe. Front. Physiol. 5:288. doi: $10.3389 /$ fphys.2014.00288

This article was submitted to Integrative Physiology, a section of the journal Frontiers in Physiology.

Copyright (c) 2014 de Carvalho, Patrone, Taxini, Biancardi, Vicente and Gargaglioni. This is an open-access article distributed under the terms of the Creative Commons Attribution License (CC BY). The use, distribution or reproduction in other forums is permitted, provided the original author(s) or licensor are credited and that the original publication in this journal is cited, in accordance with accepted academic practice. No use, distribution or reproduction is permitted which does not comply with these terms. 